NASA/TM—2006-214465

\title{
Improved Seals for High Temperature Airframe Applications
}

Jeffrey J. DeMange

University of Toledo, Toledo, Ohio

Patrick H. Dunlap and Bruce M. Steinetz

Glenn Research Center, Cleveland, Ohio 


\section{NASA STI Program . . . in Profile}

Since its founding, NASA has been dedicated to the advancement of aeronautics and space science. The NASA Scientific and Technical Information (STI) program plays a key part in helping NASA maintain this important role.

The NASA STI Program operates under the auspices of the Agency Chief Information Officer. It collects, organizes, provides for archiving, and disseminates NASA's STI. The NASA STI program provides access to the NASA Aeronautics and Space Database and its public interface, the NASA Technical Reports Server, thus providing one of the largest collections of aeronautical and space science STI in the world. Results are published in both non-NASA channels and by NASA in the NASA STI Report Series, which includes the following report types:

- TECHNICAL PUBLICATION. Reports of completed research or a major significant phase of research that present the results of NASA programs and include extensive data or theoretical analysis. Includes compilations of significant scientific and technical data and information deemed to be of continuing reference value. NASA counterpart of peer-reviewed formal professional papers but has less stringent limitations on manuscript length and extent of graphic presentations.

- TECHNICAL MEMORANDUM. Scientific and technical findings that are preliminary or of specialized interest, e.g., quick release reports, working papers, and bibliographies that contain minimal annotation. Does not contain extensive analysis.

- CONTRACTOR REPORT. Scientific and technical findings by NASA-sponsored contractors and grantees.
- CONFERENCE PUBLICATION. Collected papers from scientific and technical conferences, symposia, seminars, or other meetings sponsored or cosponsored by NASA.

- SPECIAL PUBLICATION. Scientific, technical, or historical information from NASA programs, projects, and missions, often concerned with subjects having substantial public interest.

- TECHNICAL TRANSLATION. Englishlanguage translations of foreign scientific and technical material pertinent to NASA's mission.

Specialized services also include creating custom thesauri, building customized databases, organizing and publishing research results.

For more information about the NASA STI program, see the following:

- Access the NASA STI program home page at http://www.sti.nasa.gov

- E-mail your question via the Internet to help@sti.nasa.gov

- Fax your question to the NASA STI Help Desk at 301-621-0134

- Telephone the NASA STI Help Desk at 301-621-0390

- Write to:

NASA STI Help Desk

NASA Center for AeroSpace Information 7121 Standard Drive Hanover, MD 21076-1320 
NASA/TM-2006-214465

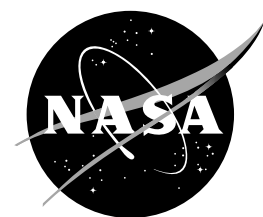

\section{Improved Seals for High Temperature Airframe Applications}

Jeffrey J. DeMange

University of Toledo, Toledo, Ohio

Patrick H. Dunlap and Bruce M. Steinetz

Glenn Research Center, Cleveland, Ohio

Prepared for the 42nd Joint Propulsion Conference and Exhibit cosponsored by AIAA, ASME, SAE, and ASEE

Sacramento, California, July 9-12, 2006

National Aeronautics and

Space Administration

Glenn Research Center

Cleveland, Ohio 44135 


\section{Acknowledgments}

The authors would like to thank Bruce Bond (Jackson-Bond, LLC) for supplying the seal samples. They would also like to acknowledge the technical contributions of Shawn Taylor (University of Toledo) and Frank Ritzert (NASA GRC).

In addition, they wish to acknowledge the contributions of Dick Tashjian (QSS) and Efrain Patino (QSS)

in assisting with testing preparation.

This report contains preliminary findings, subject to revision as analysis proceeds.

Trade names and trademarks are used in this report for identification only. Their usage does not constitute an official endorsement, either expressed or implied, by the National Aeronautics and Space Administration.

Level of Review: This material has been technically reviewed by technical management.

Available from

NASA Center for Aerospace Information 7121 Standard Drive

Hanover, MD 21076-1320
National Technical Information Service 5285 Port Royal Road Springfield, VA 22161 


\title{
Improved Seals for High Temperature Airframe Applications
}

\author{
Jeffrey J. DeMange \\ University of Toledo \\ Toledo, Ohio 43606 \\ Patrick H. Dunlap and Bruce M. Steinetz \\ National Aeronautics and Space Administration \\ Glenn Research Center \\ Cleveland, Ohio 44135
}

\begin{abstract}
Current thermal barrier seals, such as those used on the Space Shuttle, are insufficient to fully meet the demands of future hypersonic vehicles and reentry spacecraft. Previous investigations have demonstrated limited usage temperatures, as evidenced by a decreased ability to maintain sealing effectiveness at high temperatures (i.e., inadequate resiliency). In order to improve resiliency at elevated temperatures, Rene 41 (Allvac) was substituted for Inconel X-750 (Special Metals Corp.) as the spring tube material in the existing seal design. A seal construction incorporating the Rene 41 spring tube was fabricated and tested against the baseline Inconel X-750 spring tube seal. Although resiliency improvements were not as dramatic as in previous tests with the spring tubes alone, seals incorporating the Rene 41 spring tube exhibited an average 20 percent resiliency enhancement up to $1750^{\circ} \mathrm{F}$ when compared to seals containing the Inconel spring tube. In addition, the seals with the Rene 41 spring tubes showed less reduction in resiliency as temperatures increased above $1200^{\circ} \mathrm{F}$. Results also indicated the Saffil (Saffil Ltd.) insulation in the core of the seal contributed more to resiliency than previously thought. Leakage data did not demonstrate an improvement with the seal containing the Rene 41 spring tube. However, based upon resiliency results, one could reasonably expect the Rene 41 version of the seal to track gap openings over a wider range. Therefore it would exhibit lower leakage than the Inconel X-750 version as the seal gap opens during a typical mission.
\end{abstract}

\section{Nomenclature}

$\Delta_{n-1}=$ maximum displacement applied during cycle $n-1$

$\delta_{\mathrm{n}} \quad=$ permanent set in sample as determined when contact occurs (i.e., load is detected)

\section{Introduction}

High temperature airframe seals have been identified as a critical technology in the development of future spaceaccess vehicles. The current Shuttle orbiters require seals for their elevons, body flaps, landing gear doors, and other access doors. In these locations the depth of section is large enough that relatively low temperature $\left(<1500^{\circ} \mathrm{F}\right)$ seals can be recessed a distance away from the outer mold line (OML) at the end of a tortuous air path, thereby isolating the seals from high heating rates. In addition, redundant thermal barriers can be used to reduce the temperature in a "staged" fashion moving inward from the OML. Smaller reentry vehicles recently developed (e.g., X-37, X-38 Crew Return Vehicle) or under development (e.g., Falcon vehicle) have less space allocated for seals (fig. 1). This pushes the seals closer to or at the edge of the OML and increases their operating temperature. Furthermore, the Shuttle's highly insulating tile system keeps heat from being conducted to the seals, while new vehicles are embracing ceramic matrix composite (CMC) structures (ref. 1). A combination of heat conduction through these higher conductivity CMC structures, heat convection to the seals, and an inability to radiate heat from seal gaps results in seal temperatures approaching, or in some cases, exceeding $2000^{\circ} \mathrm{F}$. 


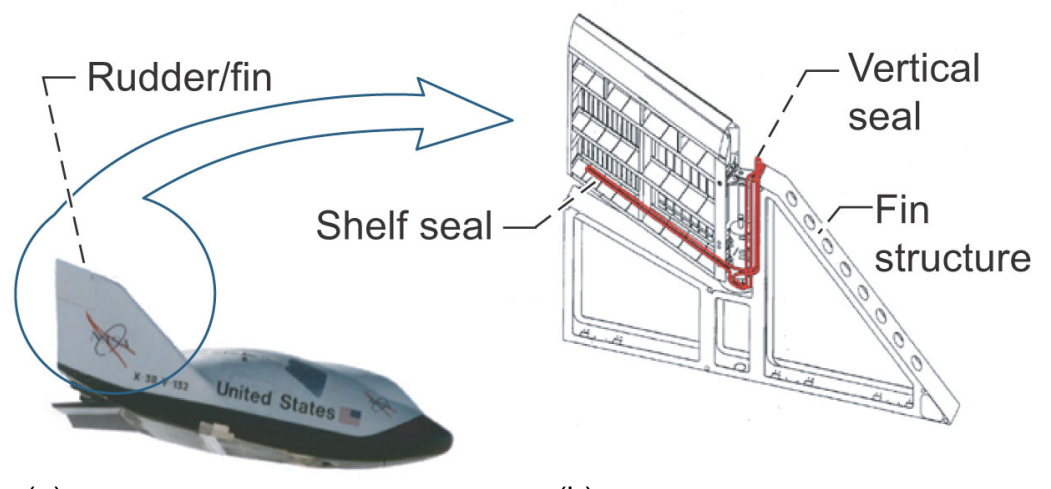

(a)

(b)

Figure 1.-(a) Photograph of X-38 Crew Return Vehicle and (b) schematic of rudder control surface seals.

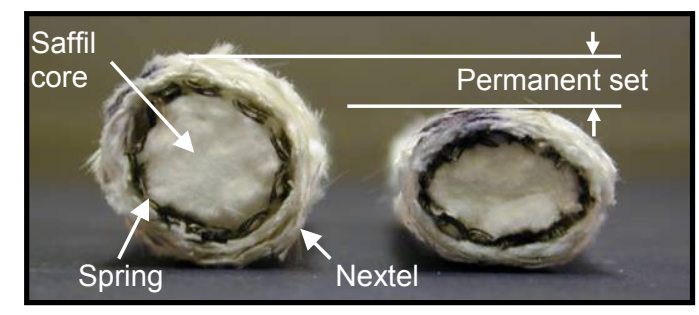

Figure 2.-Photograph showing permanent set in baseline control surface seal after 30 percent compression at $1900^{\circ} \mathrm{F}$.

A flexible thermal barrier was developed during the 1970's to be used in several locations on the Space Shuttle orbiters including the main landing gear doors, the orbiter external tank umbilical door, and the payload bay door vents (ref. 2). It was also the baseline seal design for the rudder/fin location of the X-38 vehicle (fig. 1) (ref. 3). This seal has a nominal diameter of about 0.62 in. and consists of an Inconel X-750 (also denoted as IN X-750) spring tube stuffed with Saffil batting and overbraided with two layers of Nextel (3M) 312 ceramic sleeving (fig. 2). Unfortunately these seal lose their resiliency and take on a large permanent set when they are compressed at high temperatures (fig. 2). Permanent set limits the ability of a seal to conform to movements of the opposing sealing surface caused by structural and thermal loads and increases the chance of hot gas flow past the seal. Under these conditions, hot gas flow could reach underlying temperature-sensitive structures and damage them, leading to either degraded vehicle control or possible loss of vehicle and crew.

The primary element believed to provide resiliency in the baseline seal is the metallic spring tube. The current spring tube material, Inconel X-750, dramatically loses strength above $1200^{\circ} \mathrm{F}$. An obvious solution to this problem would be to substitute a material that exhibits better high temperature strength properties. Rene 41 is one such material and was therefore selected as a potential replacement for the Inconel X-750 superalloy. Previous high temperature resiliency testing conducted at NASA Glenn Research Center (GRC) on the spring tube alone demonstrated significant improvements by substituting the Rene 41 for Inconel X-750 (refs. 4 to 7). As shown in figures 3 and 4 , results from these tests indicated a considerable enhancement in resiliency as well as a $\sim 275{ }^{\circ} \mathrm{F}$ improvement in maximum operating temperature through use of the Rene 41.

The purpose of the current study was to (1) confirm whether the improvements previously noted in the spring tube translated into enhanced performance when incorporated into the full construction seal and (2) to better understand the factors contributing to seal resiliency. Samples of control surface seals with either an IN-X750 or a Rene 41 spring tube were manufactured. The seals were then subjected to high temperature compression testing as well as room temperature flow testing at NASA GRC. 


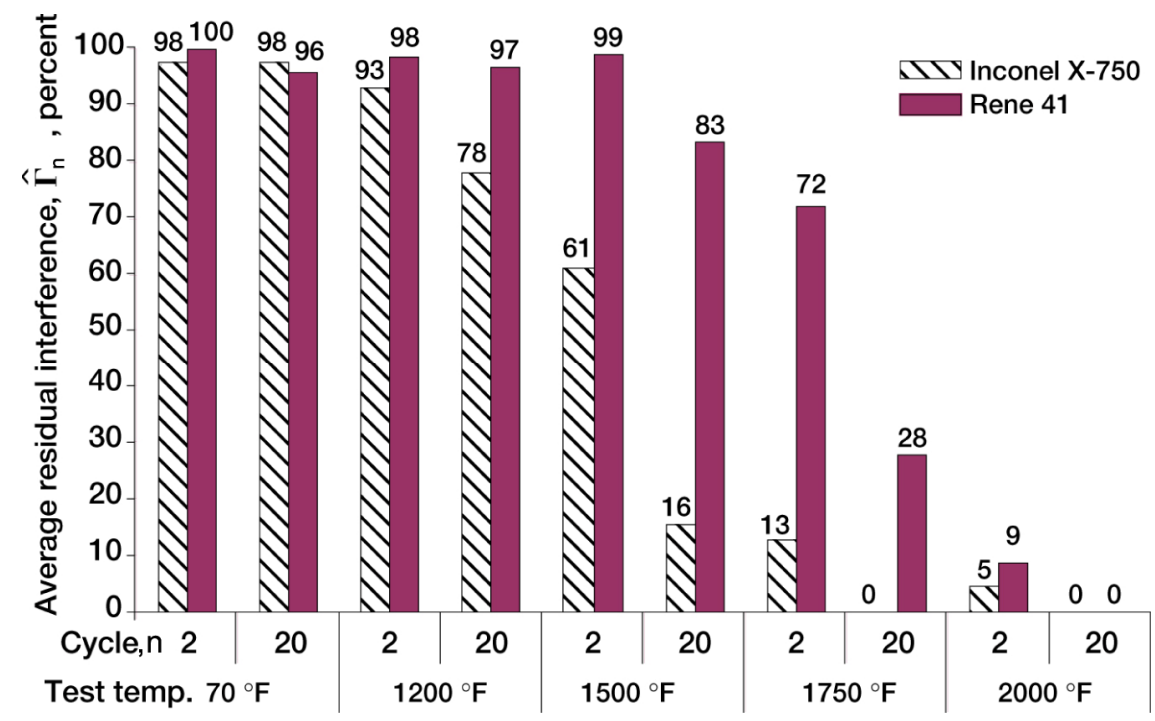

Figure 3.-Plot of high temperature resiliency for spring tubes made of Inconel X-750 and Rene 41.

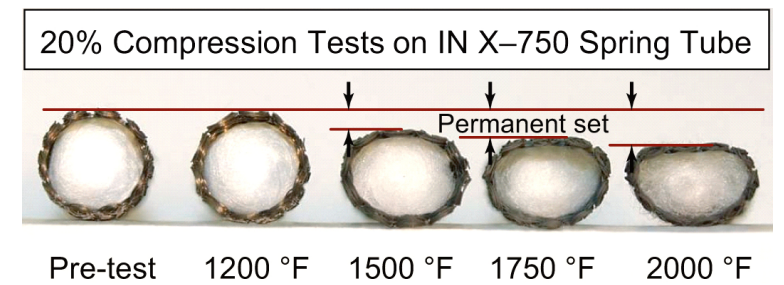

(a)

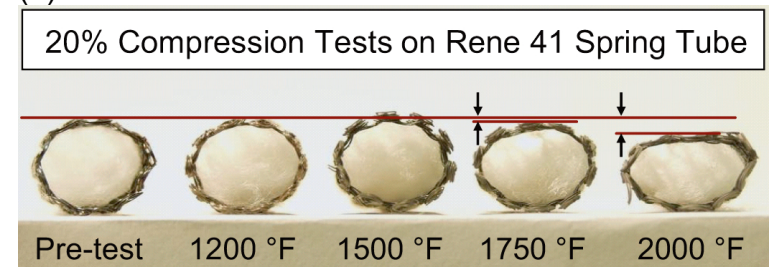

(b)

Figure 4.-Photographs of spring tubes after 20 percent compression testing at various temperatures: (a) Inconel X-750 spring tubes and (b) Rene 41 spring tubes. Note: cotton inserted in spring tube for photographic clarity only (not used during test).

\section{Experimental Procedure}

\section{A. Test Specimens}

Ten foot lengths of seals were manufactured by Jackson-Bond Enterprises, LLC. The seals were constructed using 0.5-in. thick Saffil blanket inserted into spring tubes made of Inconel X-750 or Rene 41 (0.560 \pm 0.025 -in. diameter). The amount of Saffil was selected to yield a density of approximately $7 \mathrm{lb}$ per cubic foot (pcf) of seal. The spring tubes were supplied to Jackson-Bond in a heat treated state. The Inconel X-750 spring tube was heat treated per AMS $5698\left(1300^{\circ} \mathrm{F}\right.$ for $\left.16 \mathrm{hr}\right)$. The Rene 41 spring tube was heat treated using the NASA R41C heat treatment $\left(2050^{\circ} \mathrm{F}\right.$ for $0.5 \mathrm{hr}$ and then $1400^{\circ} \mathrm{F}$ for $16 \mathrm{hr}$ ). This construction was then inserted into 2 layers of sleeving made from served Nextel 312 yarn to generate a final diameter of approximately 0.69 in. Table 1 provides nominal composition for each of the components. Seals constructed as described above are herein referred to as CS-0 (seals with IN X-750 spring tube) and CS-1 (seals with Rene 41 spring tube). 
TABLE 1.-NOMINAL COMPOSITIONS FOR SEAL COMPONENTS

\begin{tabular}{|c|c|c|c|c|c|c|c|c|}
\hline Component & Material & \multicolumn{7}{|c|}{ Nominal Composition } \\
\hline Sheath & Nextel 312 & $\begin{array}{c}62 \% \\
\mathrm{Al}_{2} \mathrm{O}_{3}\end{array}$ & $\begin{array}{l}24 \% \\
\mathrm{SiO}_{2}\end{array}$ & $\begin{array}{l}14 \% \\
\mathrm{~B}_{2} \mathrm{O}_{3}\end{array}$ & & & & \\
\hline \multirow{2}{*}{ Spring Tube } & IN X-750 & $\begin{array}{c}14-17 \% \\
\mathrm{Cr}\end{array}$ & Mo & $\begin{array}{c}1 \% \max \\
\text { Co }\end{array}$ & $\begin{array}{c}2.25-2.75 \% \\
\mathrm{Ti}\end{array}$ & $\begin{array}{c}0.4-1.0 \% \\
\mathrm{Al}\end{array}$ & $\begin{array}{c}5-9 \% \\
\mathrm{Fe}\end{array}$ & $\begin{array}{c}\mathrm{Bal} \\
\mathrm{Ni}\end{array}$ \\
\hline & Rene 41 & $\begin{array}{c}18-20 \% \\
\mathrm{Cr}\end{array}$ & $\begin{array}{c}9-10.5 \% \\
\text { Mo }\end{array}$ & $\begin{array}{c}10-12 \% \\
\text { Co }\end{array}$ & $\begin{array}{c}3-3.3 \% \\
\mathrm{Ti}\end{array}$ & $\begin{array}{c}1.4-1.8 \% \\
\mathrm{Al}\end{array}$ & $\begin{array}{c}5 \% \max \\
\mathrm{Fe}\end{array}$ & $\begin{array}{c}\mathrm{Bal} \\
\mathrm{Ni}\end{array}$ \\
\hline Core & Saffil & $\begin{array}{c}95-97 \% \\
\mathrm{Al}_{2} \mathrm{O}_{3}\end{array}$ & $\begin{array}{l}3-5 \% \\
\mathrm{SiO}_{2}\end{array}$ & & & & & \\
\hline
\end{tabular}

Prior to testing, nominal 4-in. samples were cut from the lengths of seal and these specimens were heat cleaned at $900{ }^{\circ} \mathrm{F}$ for $15 \mathrm{hr}$ to remove any organic materials (i.e., binders, etc.). Although this heating schedule was not the preferred cleaning method for Nextel, the parameters were selected to minimize any adverse temperature effects on the metallic spring tubes.

Samples of baseline heritage seals (2 layers Nextel 312/IN X-750 spring tube/6 to 9 pcf Saffil) originally manufactured by Boeing and obtained during the X-38 CRV program were also prepared. These seals measured approximately 0.650 -in. in diameter but did not require a heat cleaning cycle. Comparative testing at room temperature was performed to ensure the Jackson-Bond version of the Inconel X-750-based design provided comparable performance. This also served as a baseline to identify any differences due to seal fabrication.

To better understand seal resiliency and the contribution of individual components, the 2-layer sheath was removed from a few of the heat-cleaned Jackson-Bond samples (both CS-0 and CS-1). The spring tube and Saffil samples were then photographed and compression tested as described below.

\section{B. Test Procedure}

\section{Compression Tests}

Prior to the compression tests, each 4-in. sample was measured and weighed before and after heat cleaning. In addition, end-on photographs were taken and the diameter in the compression direction was assessed before and after each test. The seal specimens were tested in a state-of-the-art Hot Compression/Scrub Rig located at NASA GRC (fig. 5). This rig consists of a servohydraulic test frame, $3000^{\circ} \mathrm{F}$ box air furnace, and laser extensometer. For the current tests, a $100 \mathrm{lbf}$ load cell was used for measuring load (accuracy $\pm 0.05 \mathrm{lbf}$ ) and the laser extensometer (accuracy \pm 0.00025 in.) was used for evaluating displacement. Further details of the test rig can be found in the paper by Dunlap, et al (ref. 8).

As shown in table 2, exploratory compression tests were performed at room temperature to (1) compare performance of heritage seals with the same design made by Jackson Bond (CS-0) and (2) to understand the influence of seal lateral constraint (i.e., seal groove size). For these tests, a sample of the CS-0 design and two heritage seals (X-38 6 pcf and X-38 9 pcf Saffil) were compression tested between 2 flat plates. Initial contact with the seals was determined when the load reached a defined preload value (i.e., $0.05 \mathrm{lbf} / \mathrm{in}$.). The seals were then compressed 5 times at room temperature using the following cycle: compressed 20 percent at $0.002 \mathrm{in} . / \mathrm{s}$, held at maximum compression for $30 \mathrm{~s}$, and then unloaded at $0.002 \mathrm{in}$./s. A sample of the CS- 0 construction was also tested by compressing 10 cycles in a 0.625 in. groove to directly compare with previous data on the heritage seals. A test was also conducted with the CS- 0 seal installed in a 0.660 -in. groove to yield a 4 to 6 percent lateral compression across the width of the seal. This was similar to the lateral compression used in previous tests on the heritage seals ( 4 percent).

After completion of the exploratory tests and selection of a proper groove size (i.e., $0.660 \mathrm{in}$.) for the JacksonBond seals, compression tests were conducted at both room temperature and high temperatures $(1200,1500$, and $1750^{\circ} \mathrm{F}$ ), as shown in table 2. The 4-in. CS-0 and CS-1 specimens were installed in a seal holder with a 0.660-in. wide groove. Appropriate shims were placed underneath the seal to produce a nominal 1/4-in. gap between the seal holder and top platen when the seal was compressed 20 percent. The holder containing the seal was then installed inside the furnace and the sample was heated to the appropriate temperature at $500^{\circ} \mathrm{F} / \mathrm{hr}$. When the selected temperature was reached, the upper platen was lowered to achieve initial contact (defined as $0.05 \mathrm{lbf} / \mathrm{in}$. of seal). Care was exercised to ensure minimal fraying of the end fibers which might affect uniform contact conditions. The seal was then loaded at $0.002 \mathrm{in} . / \mathrm{s}$ to 20 percent compression $(0.137 \mathrm{in}$.), held for $250 \mathrm{~s}$, and then fully unloaded at 


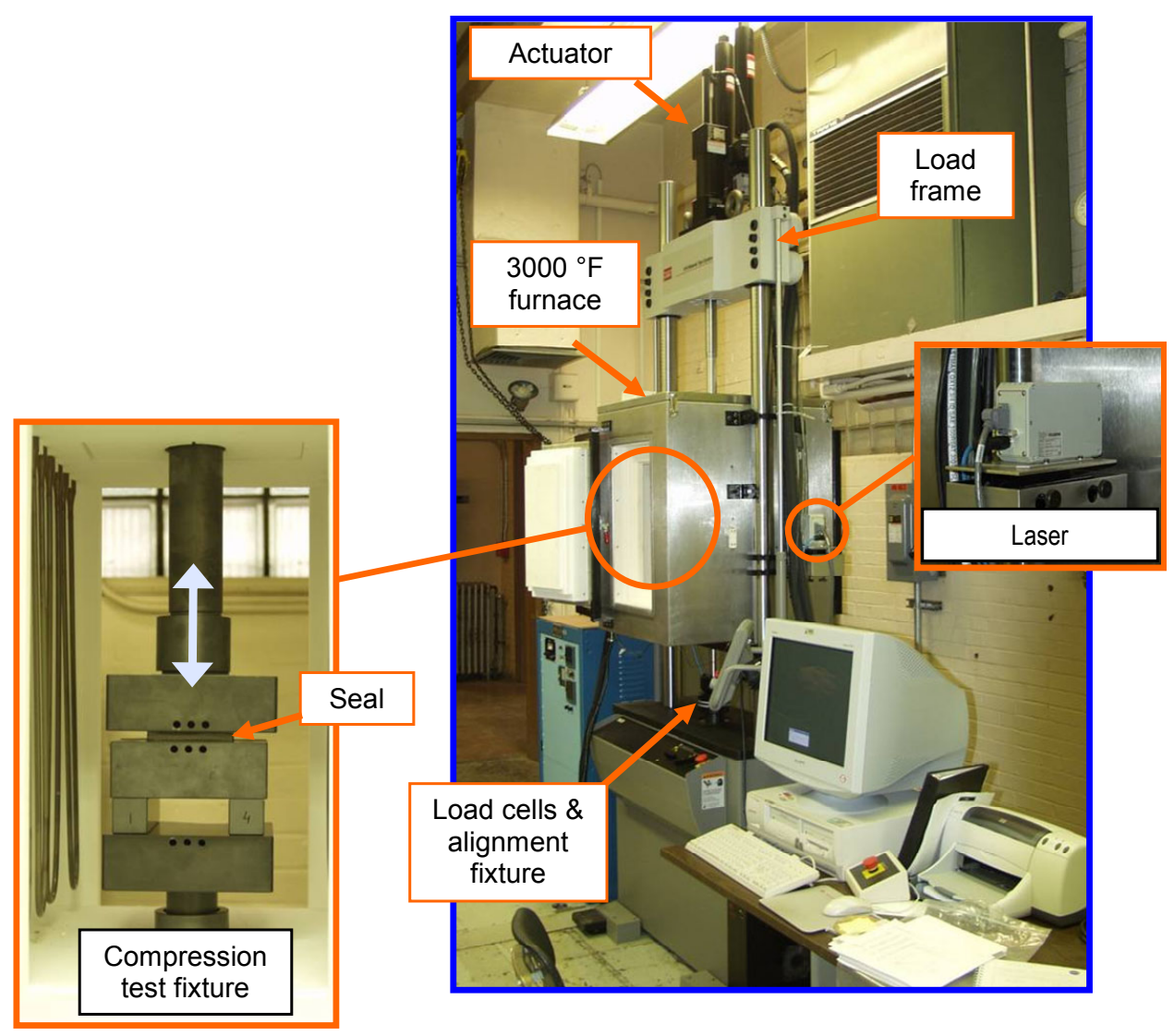

Figure 5.-Photograph of hot compression and scrub test rig showing main components: load frame, high temperature furnace, laser extensometer, and high temperature compression fixturing.

TABLE 2.-SUMMARY OF TEST PARAMETERS USED IN COMPRESSION TESTS.

\begin{tabular}{|c|c|c|c|c|c|c|c|c|c|c|}
\hline Seal & Construction & $\begin{array}{c}\text { Temp. } \\
\left({ }^{\circ} \mathrm{F}\right)\end{array}$ & No. of Tests & $\begin{array}{c}\text { Initial } \\
\text { Diam. } \\
\text { (in.) }\end{array}$ & Test Config. & $\begin{array}{l}\text { Preload } \\
\text { (Ibf/in.) }\end{array}$ & $\begin{array}{c}\text { Compression } \\
\text { (in.) }\end{array}$ & $\begin{array}{c}\text { Load/ } \\
\text { Unload Rate } \\
\text { (in./s) }\end{array}$ & $\begin{array}{l}\text { Dwell } \\
\text { (s) }\end{array}$ & $\begin{array}{l}\text { No. of } \\
\text { Cycles }\end{array}$ \\
\hline \multicolumn{11}{|c|}{ Exploratory Tests } \\
\hline CS-0 & 2L N312/IN X-750/7 pcf Saffil & 70 & 1 & 0.69 & 0.625 -in. groove & \multirow{5}{*}{0.05} & 0.137 & \multirow{5}{*}{0.002} & \multirow{5}{*}{30} & 10 \\
\hline CS-0 & 2L N312/IN X-750/7 pcf Saffil & 70 & 1 & 0.69 & 2 flat plates & & 0.137 & & & 5 \\
\hline X38 (6 pcf) & 2L N312/IN X-750/6 pcf Saffil & 70 & 1 & 0.65 & 2 flat plates & & 0.132 & & & 5 \\
\hline X38 (9 pcf) & 2L N312/IN X-750/9 pcf Saffil & 70 & 1 & 0.65 & 2 flat plates & & 0.132 & & & 5 \\
\hline CS-0 & 2L N312/IN X-750/7 pcf Saffil & 70 & 1 & 0.69 & 0.660 -in. groove & & 0.137 & & & 5 \\
\hline \multicolumn{11}{|c|}{ Tests on seals with IN X-750 Spring Tube } \\
\hline \multirow{6}{*}{ CS-0 } & 2L N312/IN X-750/7 pcf Saffil & 70 & 2 & 0.68 & 0.660 -in. groove & \multirow{6}{*}{0.05} & 0.137 & \multirow{6}{*}{0.002} & \multirow{6}{*}{250} & \multirow{6}{*}{10} \\
\hline & \begin{tabular}{|l|} 
2L N312/IN X-750/7 pcf Saffil \\
\end{tabular} & 1200 & 1 & 0.69 & 0.660 -in. groove & & 0.137 & & & \\
\hline & 2L N312/IN X-750/7 pcf Saffil & 1500 & 2 & 0.69 & 0.660 -in. groove & & 0.137 & & & \\
\hline & 2L N312/IN X-750/7 pcf Saffil & 1750 & 2 & 0.69 & 0.660 -in. groove & & 0.137 & & & \\
\hline & \begin{tabular}{|l|} 
2L N312/IN X-750/7 pcf Saffil \\
\end{tabular} & 1750 & 1 & 0.68 & 2 flat plates & & 0.207 & & & \\
\hline & IN X-750/7 pcf Saffil & 1750 & 1 & 0.55 & 0.625 -in. groove & & 0.112 & & & \\
\hline \multicolumn{11}{|c|}{ Tests on seals with Rene 41 Spring Tube } \\
\hline \multirow{6}{*}{ CS-1 } & 2L N312/Rene 41/7 pcf Saffil & 70 & 1 & 0.70 & 0.660 -in. groove & \multirow{6}{*}{0.05} & 0.137 & \multirow{6}{*}{0.002} & \multirow{6}{*}{250} & \multirow{6}{*}{10} \\
\hline & 2L N312/Rene 41/7 pcf Saffil & 1200 & 1 & 0.70 & 0.660 -in. groove & & 0.137 & & & \\
\hline & 2L N312/Rene 41/7 pcf Saffil & 1500 & 2 & 0.68 & 0.660 -in. groove & & 0.137 & & & \\
\hline & 2L N312/Rene 41/7 pcf Saffil & 1750 & 2 & 0.67 & 0.660 -in. groove & & 0.137 & & & \\
\hline & 2L N312/Rene 41/7 pcf Saffil & 1750 & 1 & 0.70 & 2 flat plates & & 0.207 & & & \\
\hline & Rene 41/7 pcf Saffil & 1750 & 1 & 0.55 & 0.625 -in. groove & & 0.112 & & & \\
\hline
\end{tabular}


0.002 in./s. This cycle was repeated 9 additional times. For room temperature tests, a carbon transfer tape was inserted between the seal and upper platen to provide an estimate of the seal contact area during the first compression cycle. The contact area and the load were used to approximate the unit load for the seals. After the first cycle, the tape was removed, the platen was lowered the appropriate amount to account for the tape thickness, and the seal was compressed an additional 9 cycles.

Additional tests were conducted at $1750{ }^{\circ} \mathrm{F}$ with the CS- 0 and CS-1 seals manufactured by Jackson-Bond to extend the understanding of seal performance and the contribution of each component to overall resiliency. Samples were compression tested between 2 flat plates to 30 percent compression $(0.207$ in.) using the same loading parameters as previously mentioned. Samples with the 2 layer Nextel sheath removed (i.e., spring tubes and Saffil only) were also tested in a 0.625 in. groove to 20 percent compression.

\section{Flow Tests}

Room temperature flow tests were performed on the seal specimens in the linear flow fixture shown in figure 6. These leakage tests were conducted on seals which were not compression tested and on each of the seal samples after compression testing (with the exception of the samples with the sheath removed). For each test, the seal was inserted in the groove of a seal holder that was mounted in the test cartridge (fig. 6(b) and (c)). The cartridge was then installed inside the flow fixture pocket. The groove was $0.660 \mathrm{in}$. wide and $4 \mathrm{in}$. long. The amount of linear compression (20 percent) applied to the seals was set by placing metal shims in the groove behind the seal. Spacer blocks (i.e., filler blocks) placed at the ends of the test seal set the flow gap at $0.25 \mathrm{in}$. The test cartridge was inserted into the flow fixture and a 0.75 -in. thick stainless steel cover plate was bolted onto the fixture. Further details of this test rig can be found in the paper by Dunlap, et al (ref. 8).
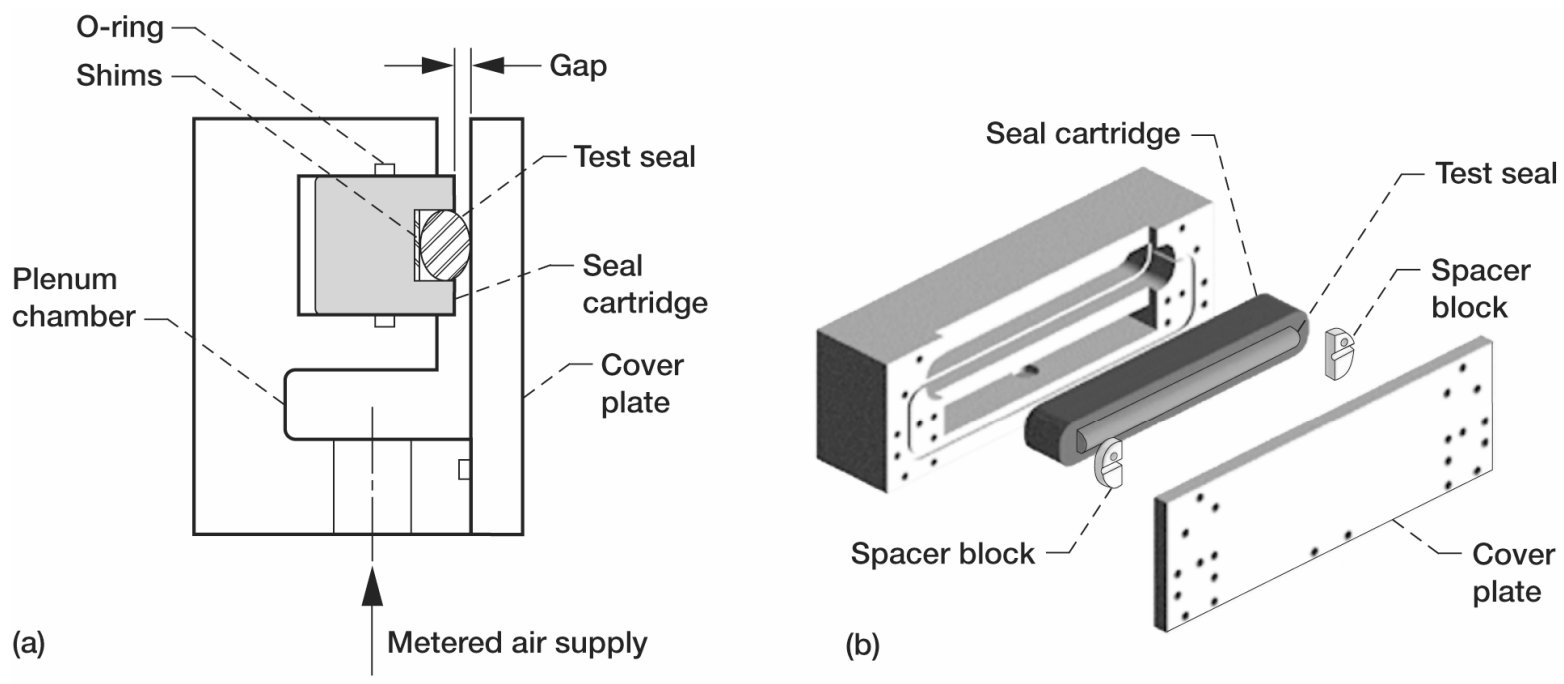

(b)

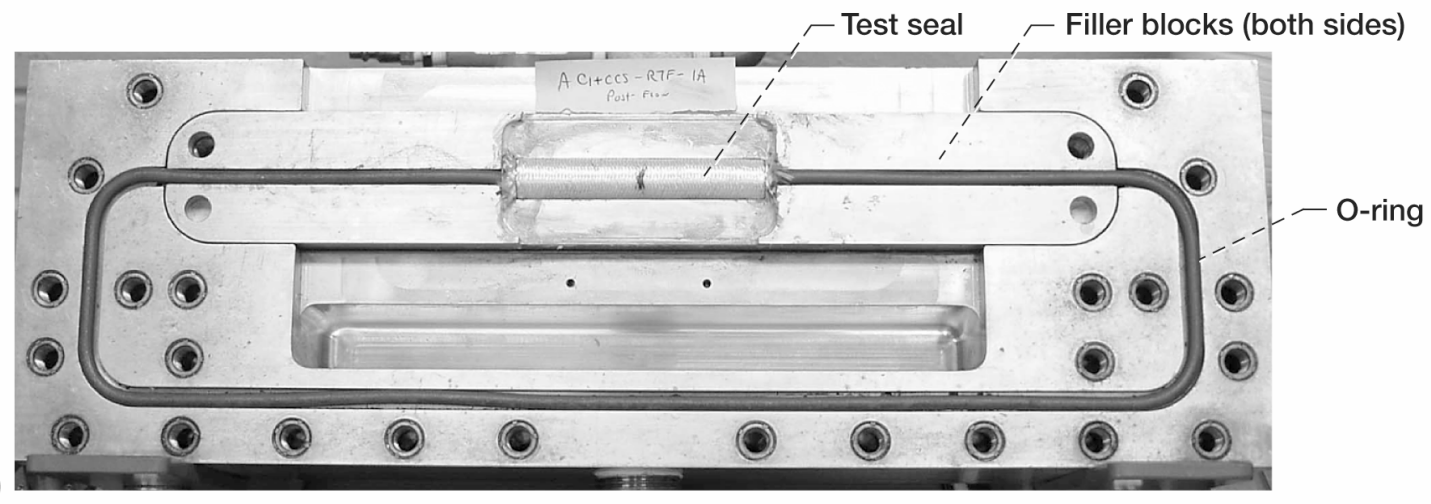

Figure 6.-Schematic of flow fixture (a) cross section and (b) isometric. (c) Photograph of front view of 4 in. seal specimen installed in flow fixture. 
Flow meters upstream of the test fixture measured the amount of air that passed through the test seal at a given pressure drop. Depending on the leakage through the seal, one of two flow meters was used: a 0 to 3.5 standard cubic feet per minute (SCFM) or a 0 to 26 SCFM flow meter, each with an accuracy of 1 percent of full scale. A pressure transducer ( 0 to 5 psid, accuracy 0.051 percent of full scale) upstream of the test seal measured the differential pressure across the seal with respect to ambient conditions, and a thermocouple measured the upstream temperature.

\section{Results and Discussion}

\section{A. Exploratory Tests}

\section{Compression Results}

A summary of the compression test results is presented in table 3. This table presents peak load and stiffness (calculated over the last 5 percent of the load-displacement curve) results for various cycles as well as residual interference data. Percent residual interference is defined as the following:

$$
\% \text { Residual Interference }(\text { cycle } n)=\frac{\Delta_{n-1}-\delta_{n}}{\Delta_{n-1}} * 100
$$

where

$$
\begin{aligned}
\Delta_{n-1} & =\text { maximum displacement applied during cycle } n-1 \\
\delta_{\mathrm{n}} & =\text { permanent set in sample as determined when contact occurs (i.e., load is detected) }
\end{aligned}
$$

Note that residual interference is a measure of seal resiliency (i.e., spring back) and the terminology is used interchangeably.

For the exploratory tests, the resiliency results appeared to indicate that the residual interference for the CS-0 sample was not as high as for the heritage seals when tested between 2 flat plates (fig. 7). Some of this discrepancy may have been due to testing variation as well as differences in seal construction. For example, while tests confirmed the CS-0 seal had a Saffil packing density of about 7 pcf, other tests on the X38-9 pcf sample indicated the packing density was closer to 12 to 14 pcf. As discussed later, this may have contributed to the difference in resiliency between the CS- 0 and heritage seals. In addition, historical data showed the resiliency of a 6 pcf seal in a groove was about 68 percent after 4 cycles and 65 percent for a 9 pcf version (ref. 4), which were comparable to results from the current study (fig. 7). 


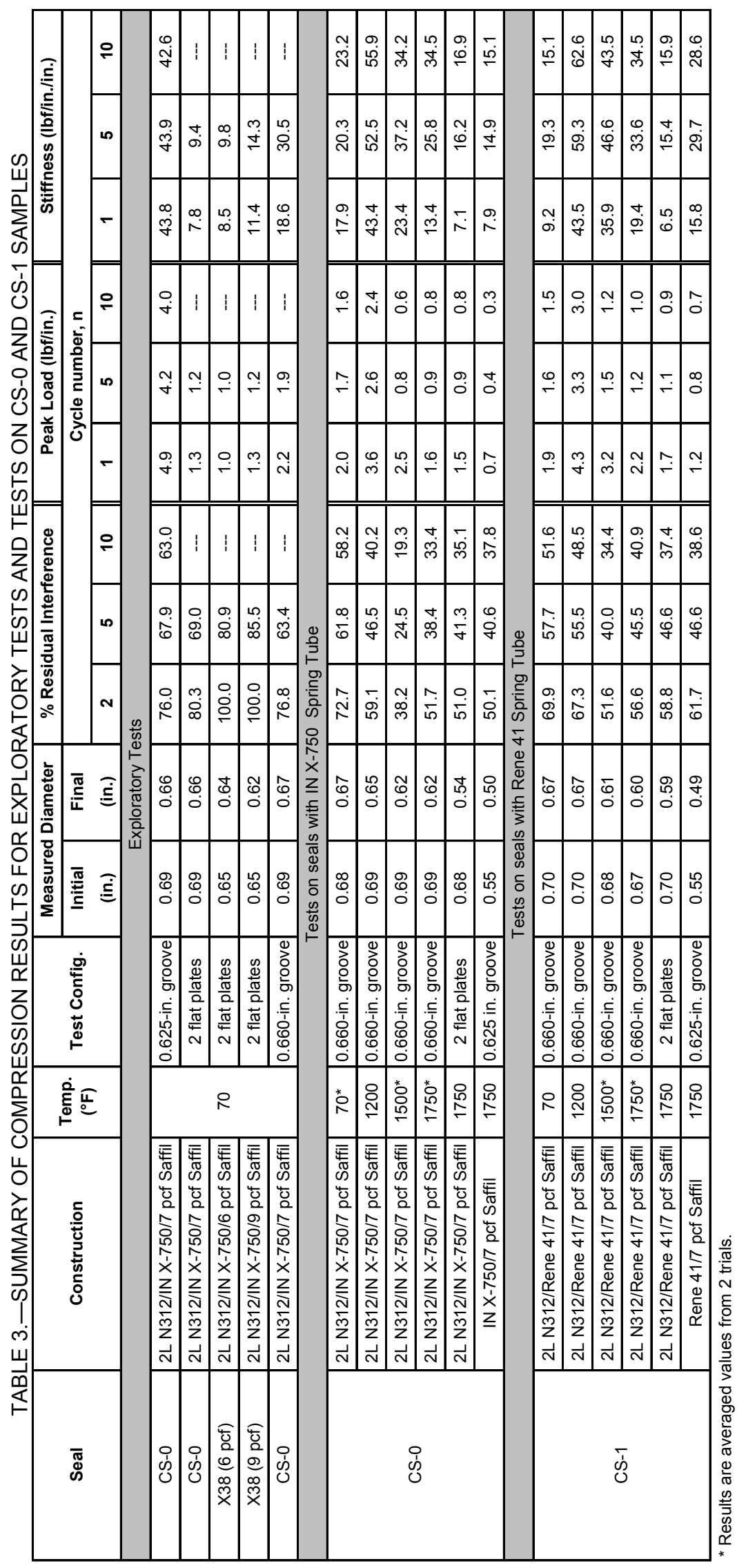




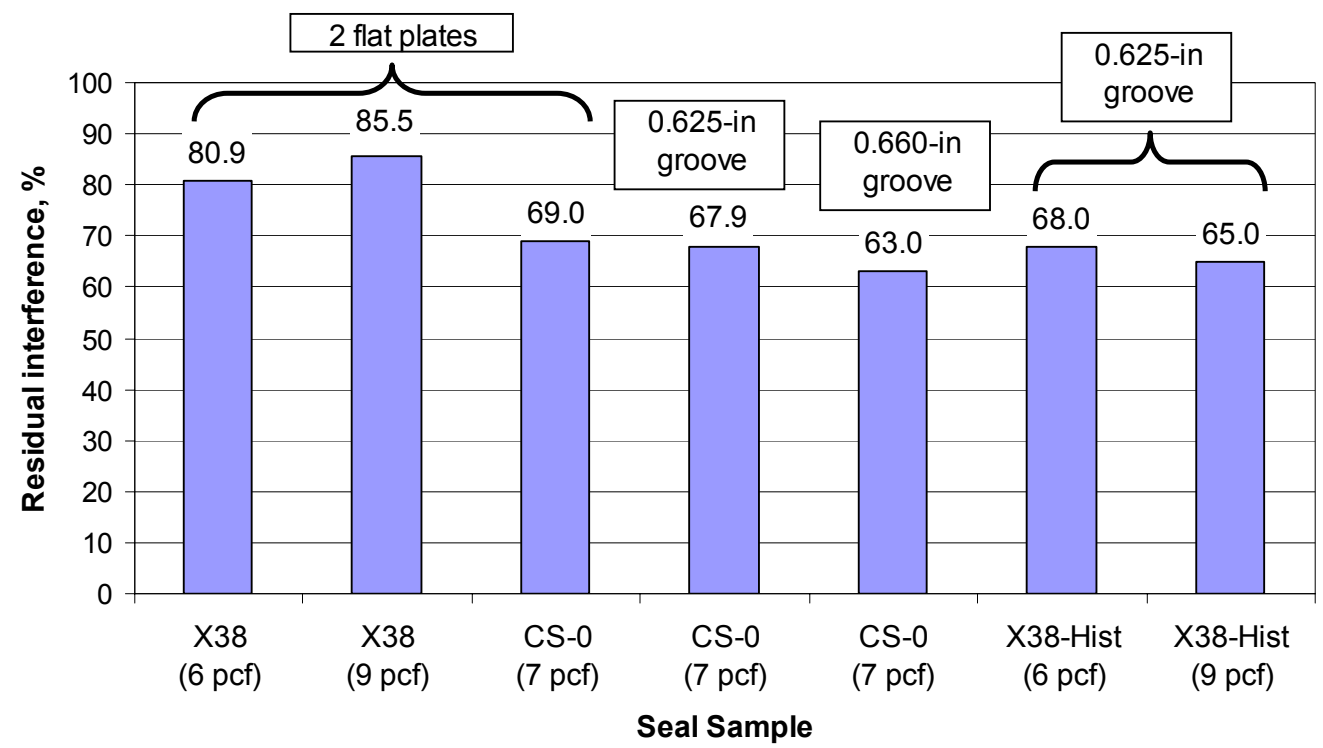

Figure 7.-Graph of residual interference after 5 compression cycles (20 percent compression) at room temperature for various seal samples. Note: Historical data shows results after 4 cycles.

As also demonstrated in this graph, the amount of lateral constraint appeared to have little impact on seal resiliency. The CS-0 seal tested between two flat plates had no lateral constraint and exhibited 69 percent resiliency, while the sample tested in a 0.625 -in. groove was under approximately 9 percent lateral compression on average. For this case, the resiliency was 67.9 percent.

One should note that the final diameter calculated from the residual interference values generally underestimated the measured (e.g., evaluated with calipers) final diameter. This was most evident in samples tested with some amount of lateral compression which resulted in friction where the seal contacted the side walls. This trend indicated that the seals were not uniformly seated on the shim underneath the seal during initial installation but became seated during the first few compression cycles. While perhaps undesirable, this is likely representative of seal installation on actual flight vehicles.

Additional results comparing performance of the CS- 0 seal and heritage control surface seals are presented in figures 8 to 10. Historical data from previous investigations is also included for comparison (ref. 4). As demonstrated in these graphs, the CS-0 sample appeared to exhibit very comparable performance to the heritage seals in terms of peak load, stiffness, and unit load after 5 cycles when the seals were tested in similar configurations (i.e., between 2 flat plates and with the same amount of lateral compression). For these cases, the unit load was under 5 psi and therefore would not cause any damage to typical control surface materials. However, in the test with the CS- 0 seal tested in the same size groove as the heritage seals (i.e., 0.625 -in. groove), the load and all associated measurements were significantly higher. Due to the additional lateral constraint, one would expect to see higher loads, as illustrated in figure 11. 


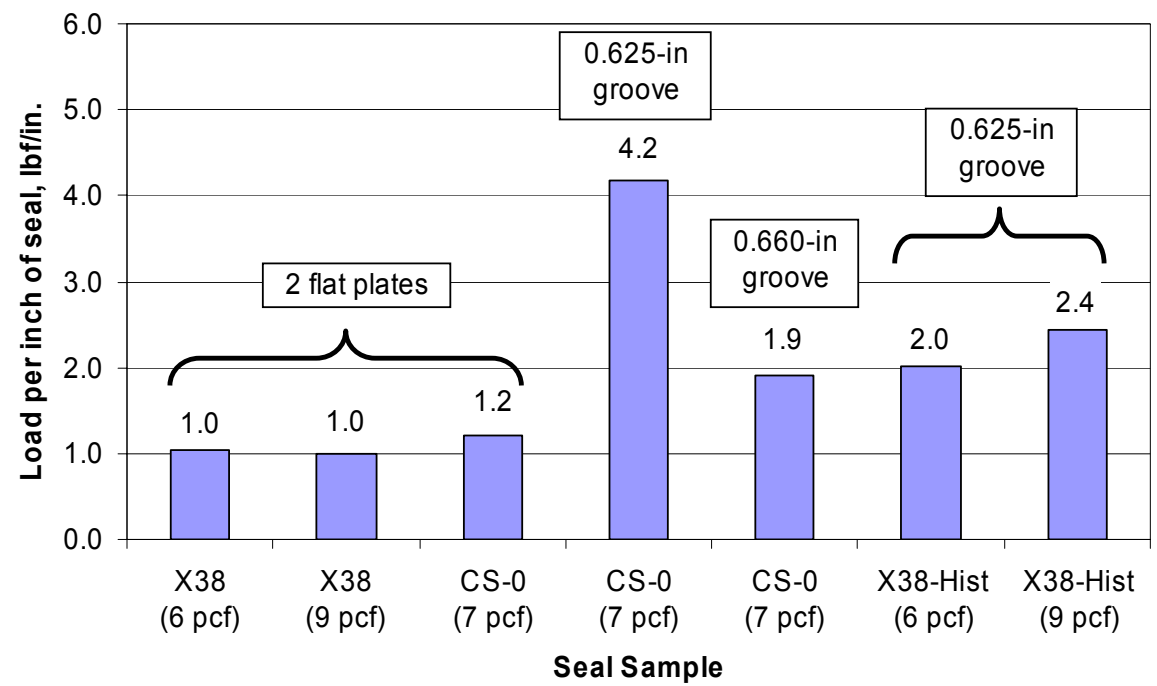

Figure 8.-Graph of peak load per inch of seal after 5 compression cycles (20 percent compression) at room temperature for various seal samples. Note: Historical data shows results after 4 cycles.

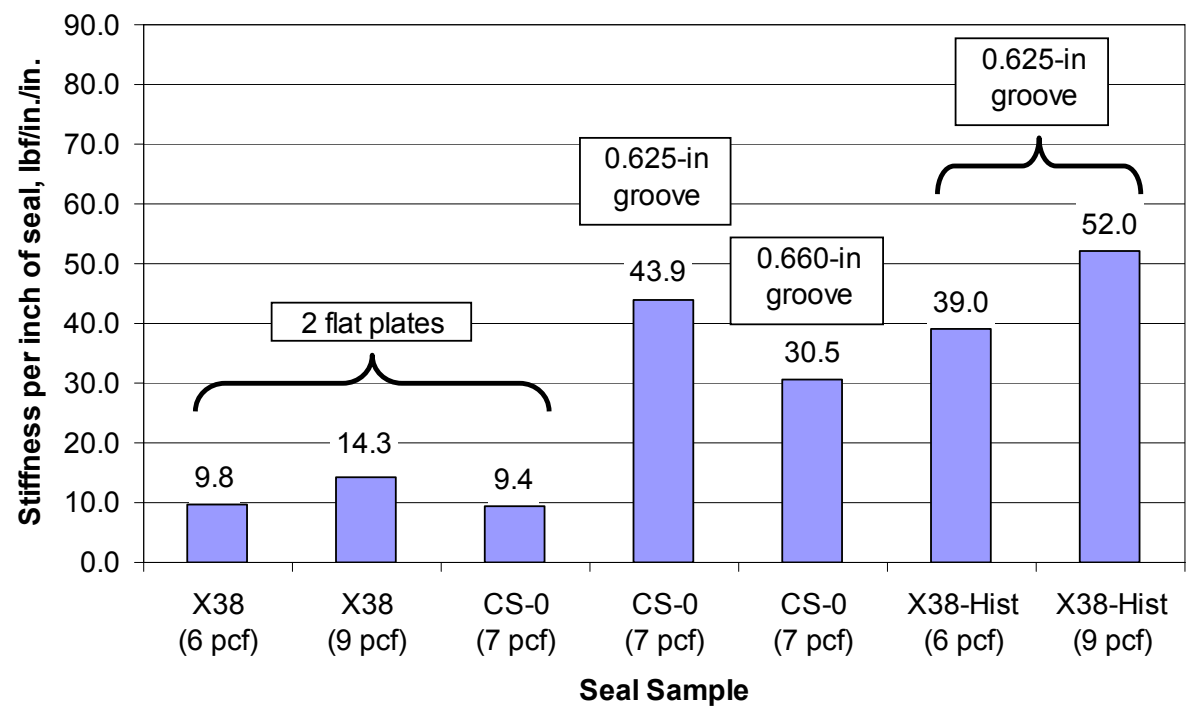

Figure 9.-Graph of seal stiffness per inch of seal after 5 compression cycles (20 percent compression) at room temperature for various seal samples. Stiffness calculated over last 5 percent of load-displacement curve. Note: Historical data shows results after 4 cycles. 


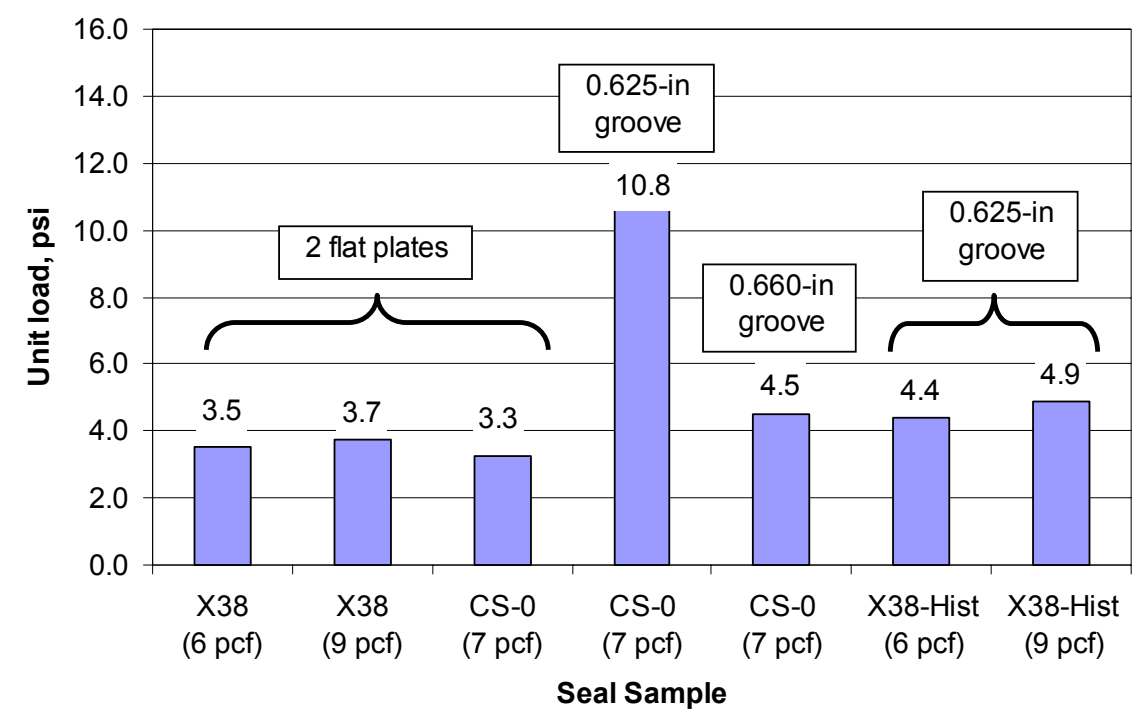

Figure 10.-Graph of seal unit load after 5 compression cycles (20 percent compression) at room temperature for various seal samples. Note: Historical data shows results after 4 cycles.

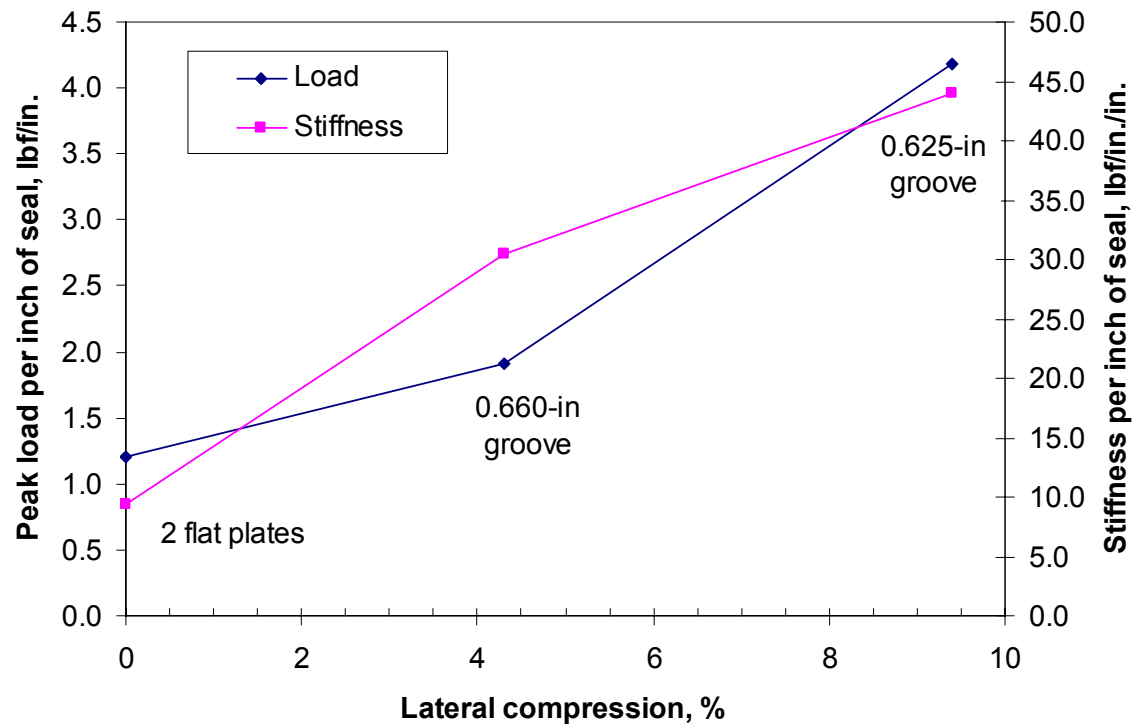

Figure 11.-Graph of seal CS-0 peak load and stiffness after 5 compression cycles (20 percent compression) at room temperature as a function of lateral compression across width of seal. 


\section{Flow Results}

Flow tests conducted on the CS- 0 seals also showed similar leakage rates when compared to historical data on the $\mathrm{X}-38$ seals. For example, with a 0.25 -in. gap at a pressure differential of 1 psig across the seal, flow for the CS-0 seal was about $0.44 \mathrm{SCFM} / \mathrm{in}$. of seal. Leakage rates for the heritage seals ranged from 0.36 to $0.53 \mathrm{SCFM} /$ in. with the same test parameters. Considering this information as well as the compression data, one could reasonably deduce that the CS-0 was a good facsimile of the heritage seals.

\section{B. Comprehensive Tests on CS-0 and CS-1}

\section{Compression Results}

Table 3 also summarizes the results of the comprehensive series of tests performed on the CS- 0 and CS- 1 seal designs. An examination of seal resiliency (fig. 12) demonstrates that for high temperatures, the seal incorporating the Rene 41 spring tube (CS-1) offered better resiliency than the seal (CS-0) using the IN X-750 spring tube. For instance, at $1500{ }^{\circ} \mathrm{F}$ after 5 cycles the CS- 0 seal exhibited 24 percent residual interference versus 40 percent for the CS-1 seal. After 10 compression cycles at $1750^{\circ} \mathrm{F}$, the CS-0 seal provided only 33 percent resiliency compared to 41 percent for the CS-1 seal. Figure 13 shows a graph of residual interference as a function of temperature for both the CS-0 and CS-1 seals after 10 load cycles. Similar to previous observations, the CS-1 seal showed slightly better resiliency (approximately 20 percent on average) than the CS- 0 seals. In addition the CS- 1 seal exhibited better performance stability than the CS-0 seal between 1200 and $1500^{\circ} \mathrm{F}$. As shown, the resiliency of the CS-0 seal dropped 50 percent between 1200 and $1500^{\circ} \mathrm{F}$, while the resiliency of the CS- 1 seal decreased by only 30 percent.

As noted in figure 13, an interesting phenomenon was observed when plotting resiliency between 1200 and $1750^{\circ} \mathrm{F}$. The residual interference decreased significantly at $1500^{\circ} \mathrm{F}$, but increased at $1750{ }^{\circ} \mathrm{F}$. While some of this may be attributable to variation in setup (e.g., seal installation) and experimental error (e.g., calculation of residual interference), the phenomenon was repeatable. The occurrence may also have been related to another interesting artifact. As shown in the photos in table 4, at $1500^{\circ} \mathrm{F}$ the Nextel sheath layers exhibited a "flat-top" appearance after compression testing and seem to show some permanent set. This was not observed in the samples tested at $1200^{\circ} \mathrm{F}$, but was seen to a lesser extent at $1750^{\circ} \mathrm{F}$. A possible mechanism for this behavior may be due to the boron in the fiber which could result in glass formation on the sheath surface at around $1500^{\circ} \mathrm{F}$. The glass may cause some of the fibers to bond together and exhibit the "flat-top" appearance noted in the photos. At $1750{ }^{\circ} \mathrm{F}$, the boron may dissociate into boria gas, and therefore limited bonding would occur. At $1200^{\circ} \mathrm{F}$, the boron still resides within the fiber and would not result in fiber bonding. A quick calculation shows the increase in resiliency between $1500{ }^{\circ} \mathrm{F}$ and $1750^{\circ} \mathrm{F}$ corresponded to approximately 0.010 to $0.020 \mathrm{in}$. of displacement. The two layers of Nextel 312 sheath were approximately 0.050 to $0.060 \mathrm{in}$. It is not unreasonable to assume that this much deformation could occur within the two layers.

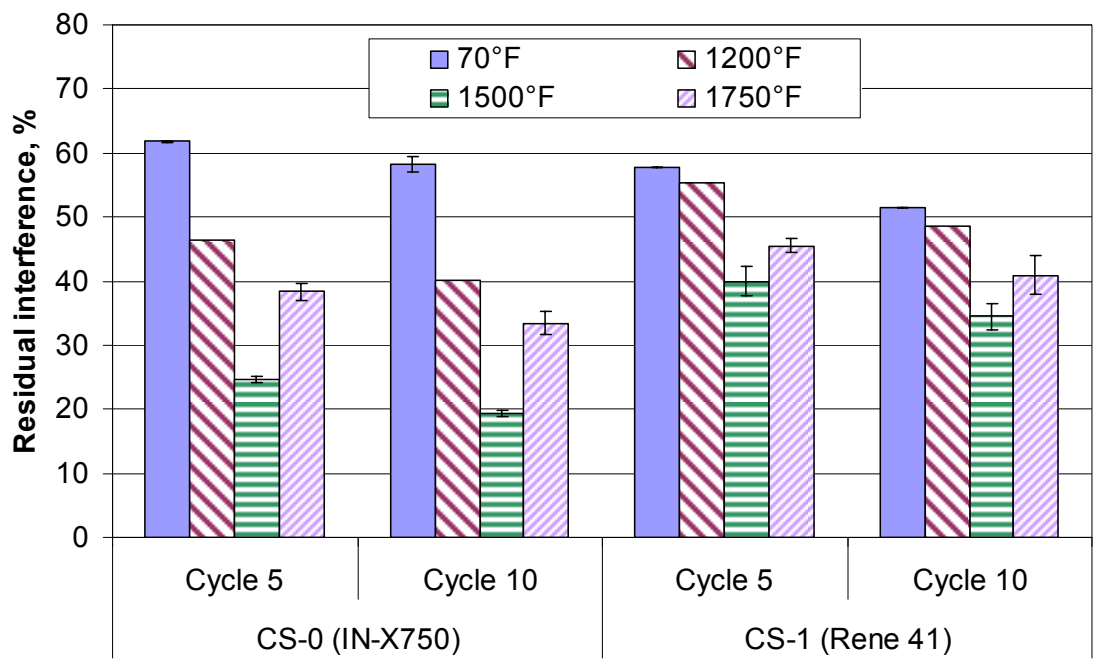

Figure 12.-Graph of seal resiliency after 5 and 10 compression cycles (20 percent compression) at various temperatures for the CS-0 and CS-1 seal constructions. Note: Error bars show range of data values. 


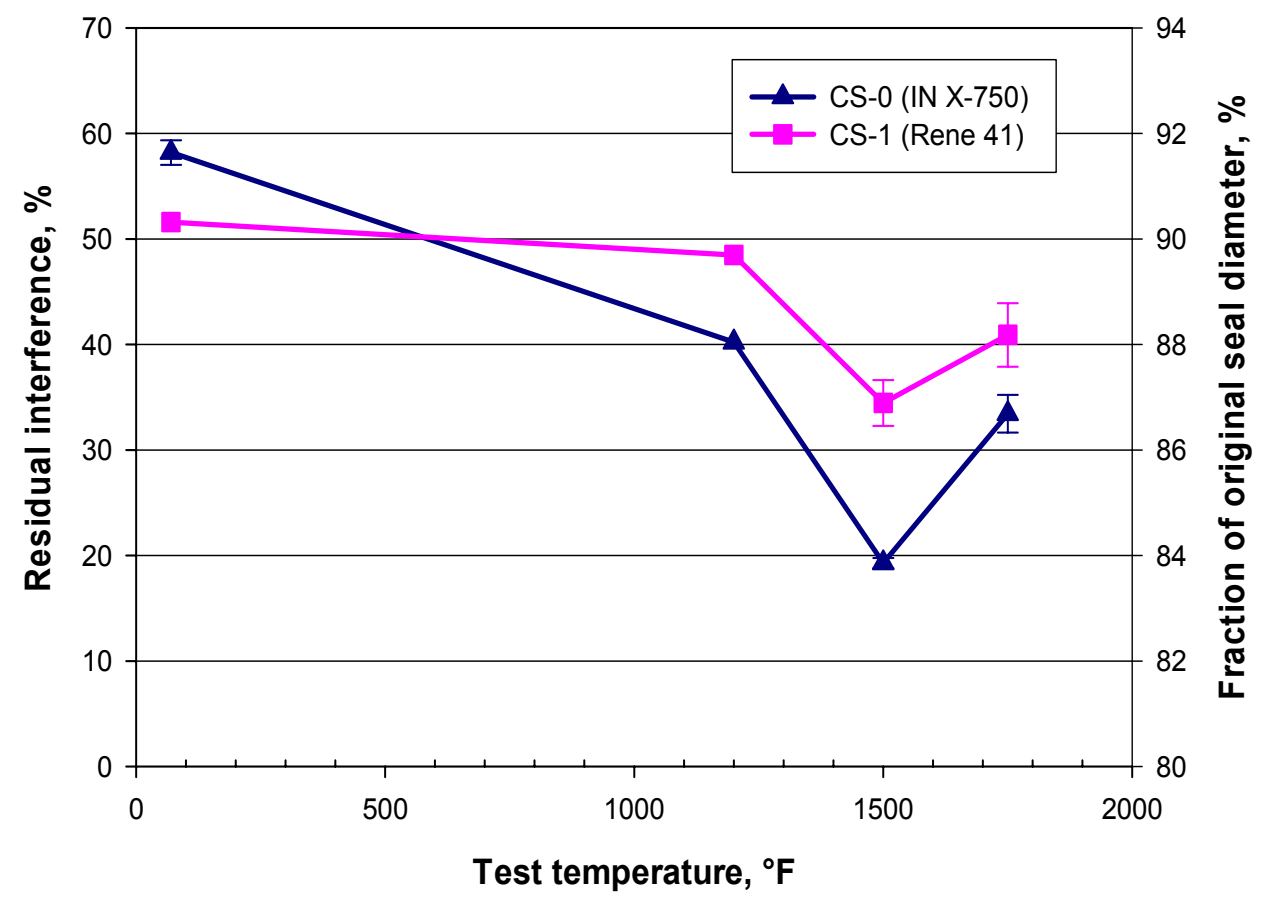

Figure 13.-Graph of seal resiliency after 10 compression cycles (20 percent compression) at various temperatures for the CS- 0 and CS- 1 seal constructions. Note: Error bars show range of data values.

The improvement in resiliency for the full seal was not as dramatic as it was with the spring tubes alone, suggesting other factors may contribute to seal resiliency. It is unlikely the thin Nextel sheath layers significantly contribute to the spring back of the seal. Tests conducted on spring tubes containing Saffil indicated the Saffil insulation may play an important role. Figure 14 presents percent residual interference results for three variations of seal construction: the full construction seals, spring tubes and Saffil (no sheath), and spring tubes (no sheath or Saffil). As demonstrated in this figure, the Saffil insulation does appear to enhance the spring back of the seal and has some inherent level of resiliency (when constrained inside the spring tube). This is best observed by considering the significant increase in performance of the Inconel spring tube when Saffil was included. A smaller gain was observed with the Rene 41 spring tube and was likely due to the fact that the Saffil only provides a certain amount of resiliency. Thus the individual component contributions are not truly additive.

Another factor which may have contributed to the resiliency difference not being as significant between the CS-0 and CS-1 seal versions was the baseline resiliency of the spring tubes. Testing on the Rene 41 lot used for the current seals showed spring tube resiliency was 30 to 40 percent lower than testing on previous lots. The reasons for this are currently under investigation, but are believed due to manufacturing and/or heat treatment variation.

As further evidence for the observation of considerable Saffil resiliency, a quick experiment was conducted to estimate how much the Saffil expands after heating if encapsulated by a low melting point material. As shown in figure 15, the Saffil blanket exhibited substantial spring back after heat cleaning. Before heat cleaning, the Saffil tube had an average diameter of 0.385 in. After heating, the Saffil expanded to over 1.12 in. in one direction, or almost $3 \mathrm{x}$ the original size. This expansion occurred in the thickness direction of the blanket which is stitched by the manufacturer to achieve the final thickness of 0.5 in. Although this might suggest the seals would exhibit anisotropy, the seals were fabricated in such a way to minimize any preferred direction. 


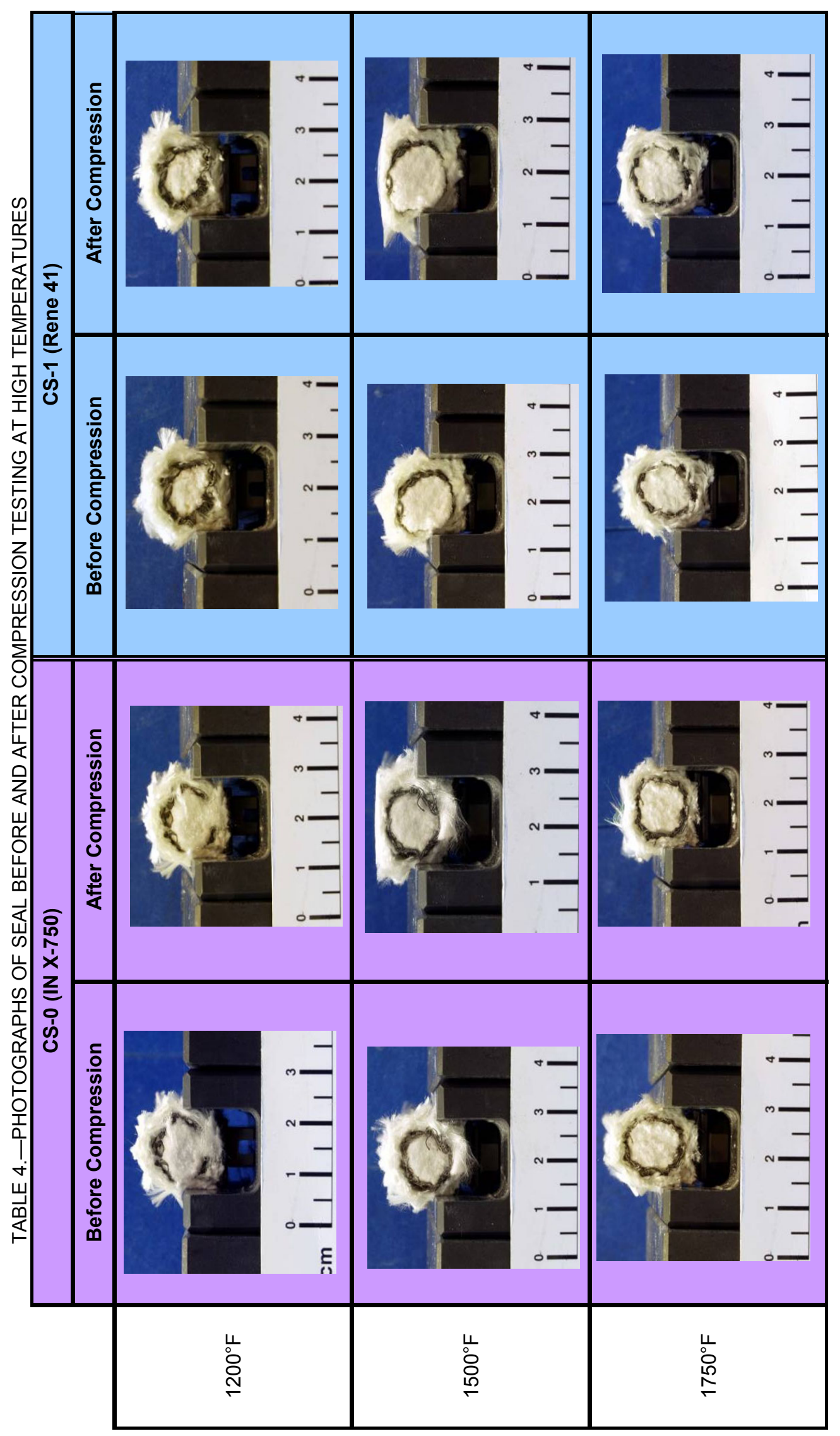




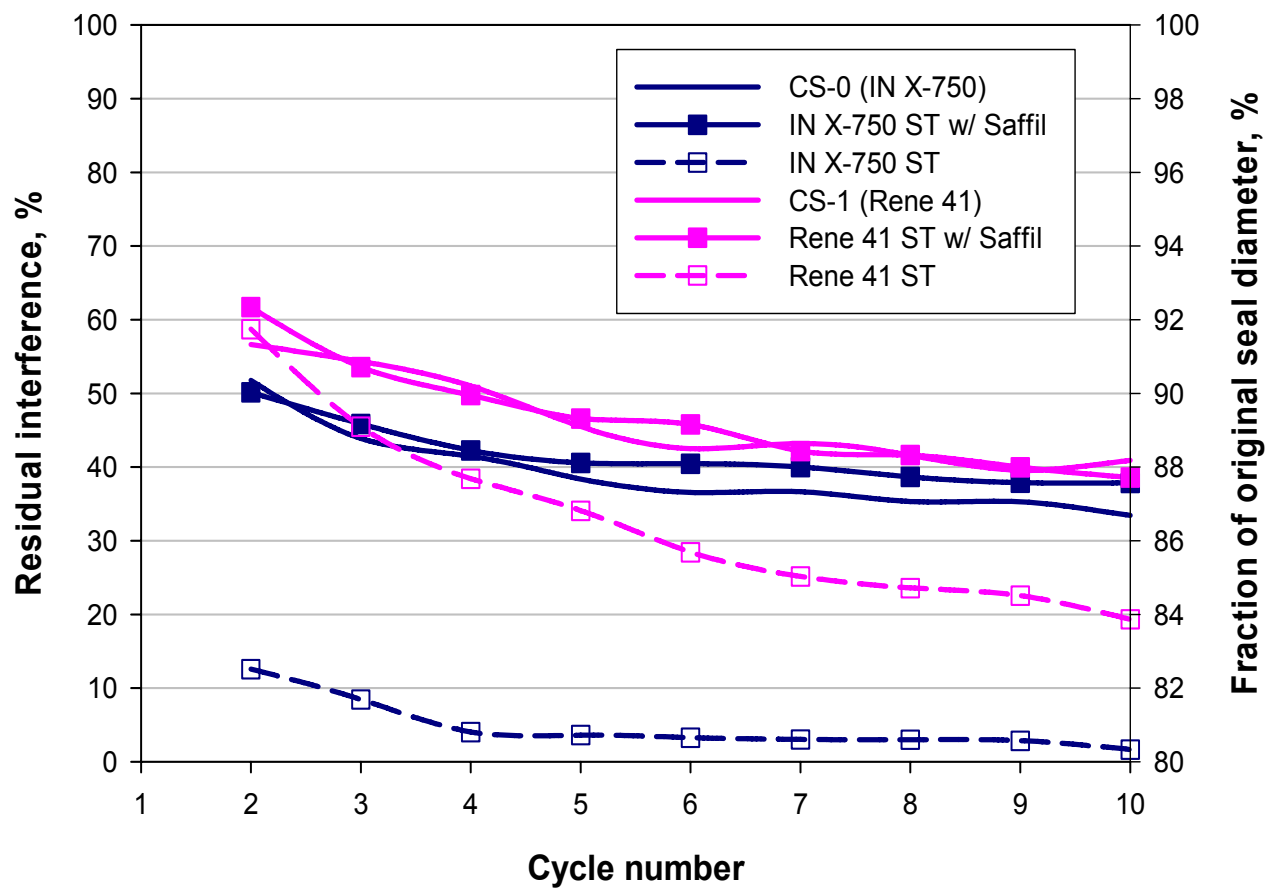

Figure 14.-Graph of seal resiliency at $1750^{\circ} \mathrm{F}$ (20 percent compression) versus cycle number comparing various constructions of the seal samples. Note: ST = spring tube.

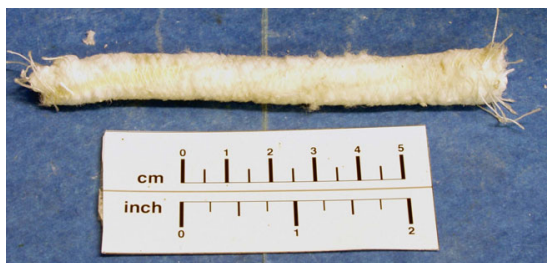

(a)

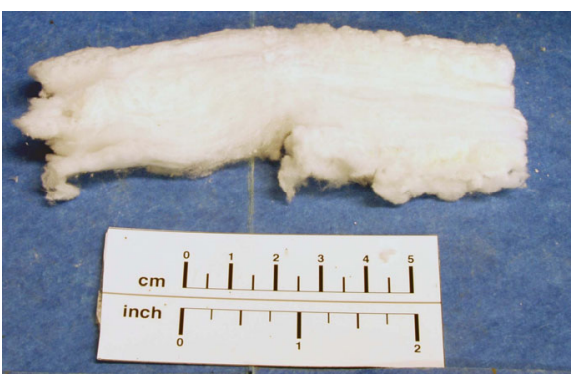

(b)

Figure 15.-Photographs of Saffil insulation (a) before and (b) after heat cleaning (900 $\left.{ }^{\circ} \mathrm{F}, 15 \mathrm{hr}\right)$.

Figure 16 presents resiliency results for both seals when tested at 30 percent compression between two flat plates at $1750^{\circ} \mathrm{F}$. As demonstrated here, the CS- 1 sample appeared to exhibit marginally better behavior than the CS-0 seal.

A representative plot comparing the peak loads for the CS-0 and the CS- 1 seals is presented in figure 17 . The peak loads at $1750^{\circ} \mathrm{F}$ of the CS-1 seals were somewhat higher than those of the CS- 0 seals. As shown in figure 17, the CS-1 loads were about 10 percent higher than the CS-0 samples between flat plates and approximately 30 to 40 percent higher when tested in a 0.660 -in groove. The decrease in cycle 10 peak load relative to cycle 1 load, which serves as another indication of resiliency, was not appreciably different between the two samples for either loading configuration.

A graph of seal peak load and stiffness versus cycle number at $1750^{\circ} \mathrm{F}$ is shown in figure 18 . As demonstrated in the graph for both samples, the load decreased with cycle number while stiffness generally increased. This is not surprising as one would expect the load to decrease as permanent set or compaction occurs and the loading platen must travel further before contacting the seal. In the same manner, after permanent set and compaction occur, the seal is denser and therefore exhibits a higher stiffness. As noted previously, this plot also shows the CS- 1 sample displayed higher load and stiffness values than the CS-0 sample. 


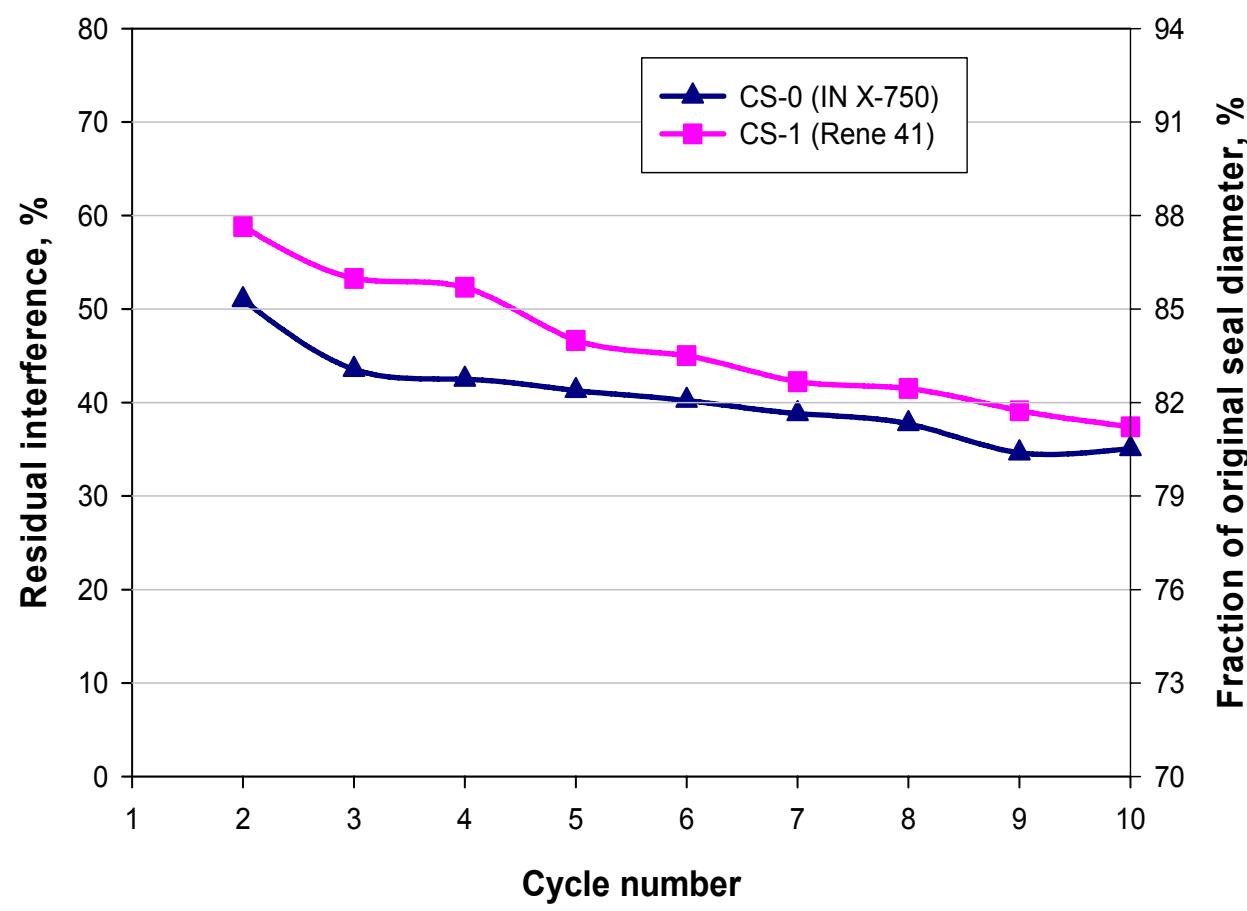

Figure 16.-Graph of seal resiliency at $1750^{\circ} \mathrm{F}$ (30 percent compression) as a function of compression cycle for CS-0 and CS-1 samples compressed between 2 flat plates.

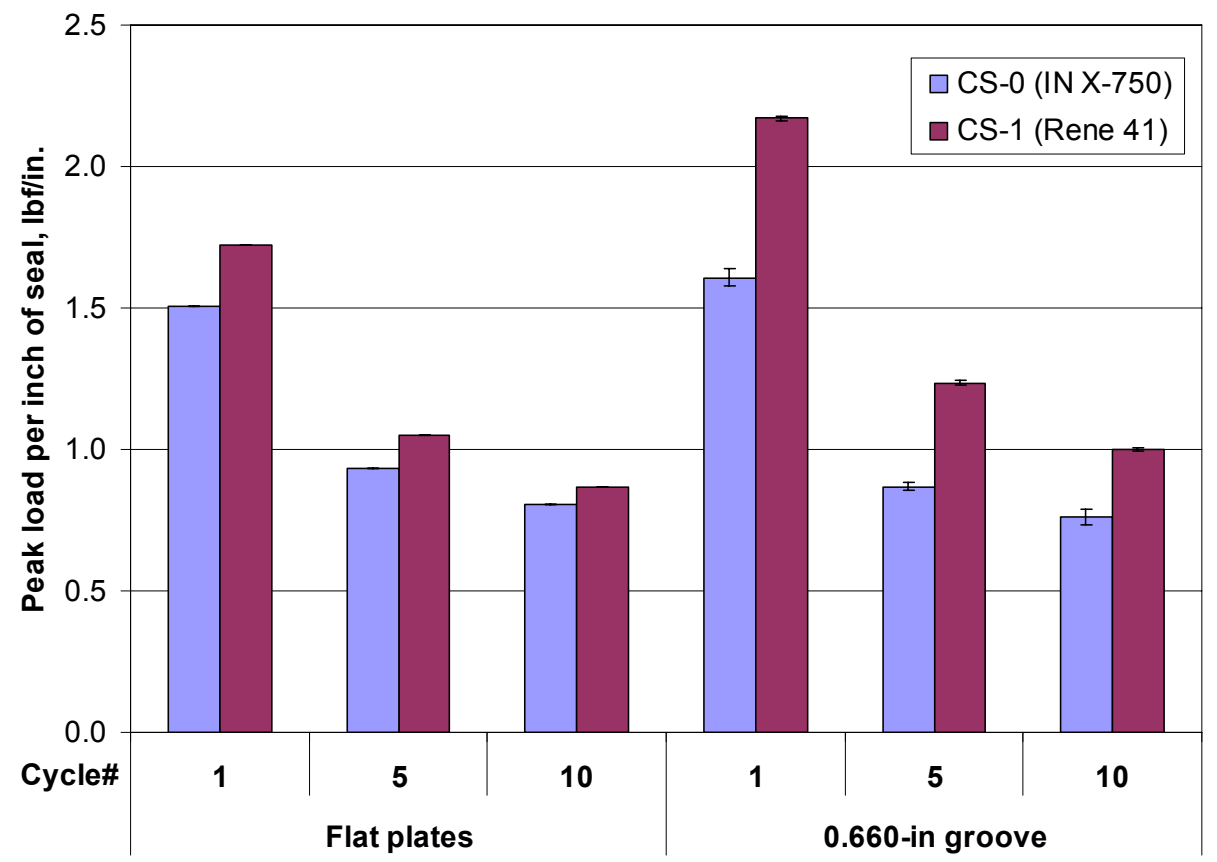

Figure 17.-Graph of seal peak load at $1750^{\circ} \mathrm{F}$ as a function of cycle number and loading configuration for CS-0 and CS-1 samples. Note: Error bars show range of data values. 


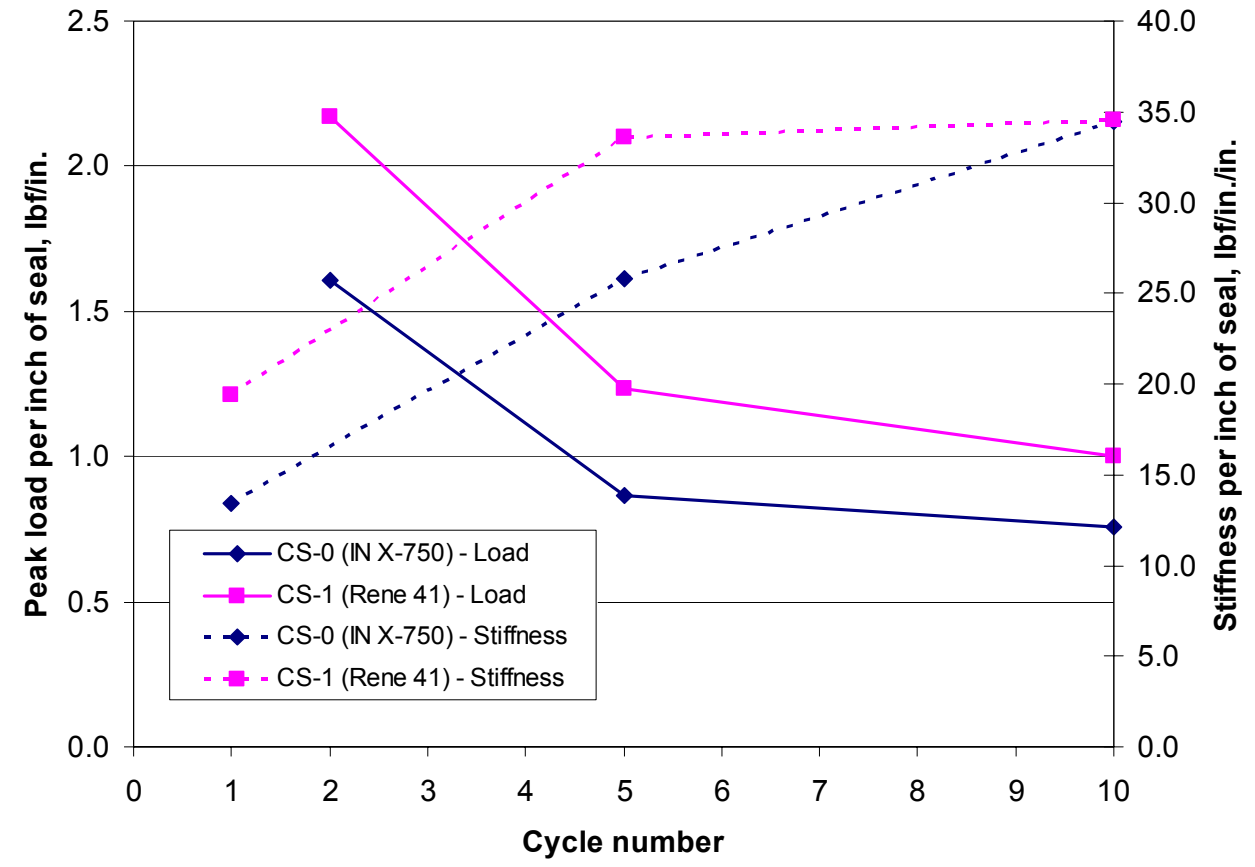

Figure 18.-Graph of seal peak load and stiffness at $1750^{\circ} \mathrm{F}$ as a function of cycle number for CS-0 and CS-1 samples. Note: Seals tested in 0.660-in. groove.

An examination of load as a function of temperature yields an unclear trend. For the current tests, the loads appeared to peak around $1200^{\circ} \mathrm{F}$. In general, one would expect load to decrease with increasing temperature. Previous testing of the spring tube by itself illustrated this trend (ref. 5). It is unknown how the other components (especially the Saffil) would perform under compression and how they might contribute to this observation. Further investigations will be required to resolve these questions.

\section{Flow Results}

Results from flow tests before and after hot compression testing are presented in figure 19. Although the results indicated that flow through the CS-1 seals was about 10 to 20 percent higher than flow through the CS-0 samples this was likely due to variations in seal construction and testing. Previous experience has shown that a 10 to 20 percent variation in flow values between similar samples is not uncommon. Although the flow results do not indicate a significant benefit in flow restriction with the CS-1 samples, it is important to note that the gap size used for these tests allowed both the CS- 0 and CS- 1 samples to remain in contact with the cover plate for all tests. If a larger gap size were used to simulate thermally-induced movement of the sealing surface it is likely the CS-0 seals would lose contact more readily due to their lower resiliency, and therefore exhibit higher flow.

There was no clear trend in leakage as a function of the temperature at which the compression tests were conducted. However, some of the same trends exhibited in the resiliency results may be exhibited here. As an example, the flow for the CS- 0 was worst at $1500^{\circ} \mathrm{F}$, similar to the resiliency results. This did not necessarily hold true for the CS-1 sample. It is important to note that while compression of a seal might prohibit it from sealing as effectively against an opposing surface, the same compression leads to compaction (i.e., densification) of the seal and in some cases, leakage may actually decrease (as long as the seal maintains contact with the opposing surface). Therefore there are competing factors which can affect flow results. 


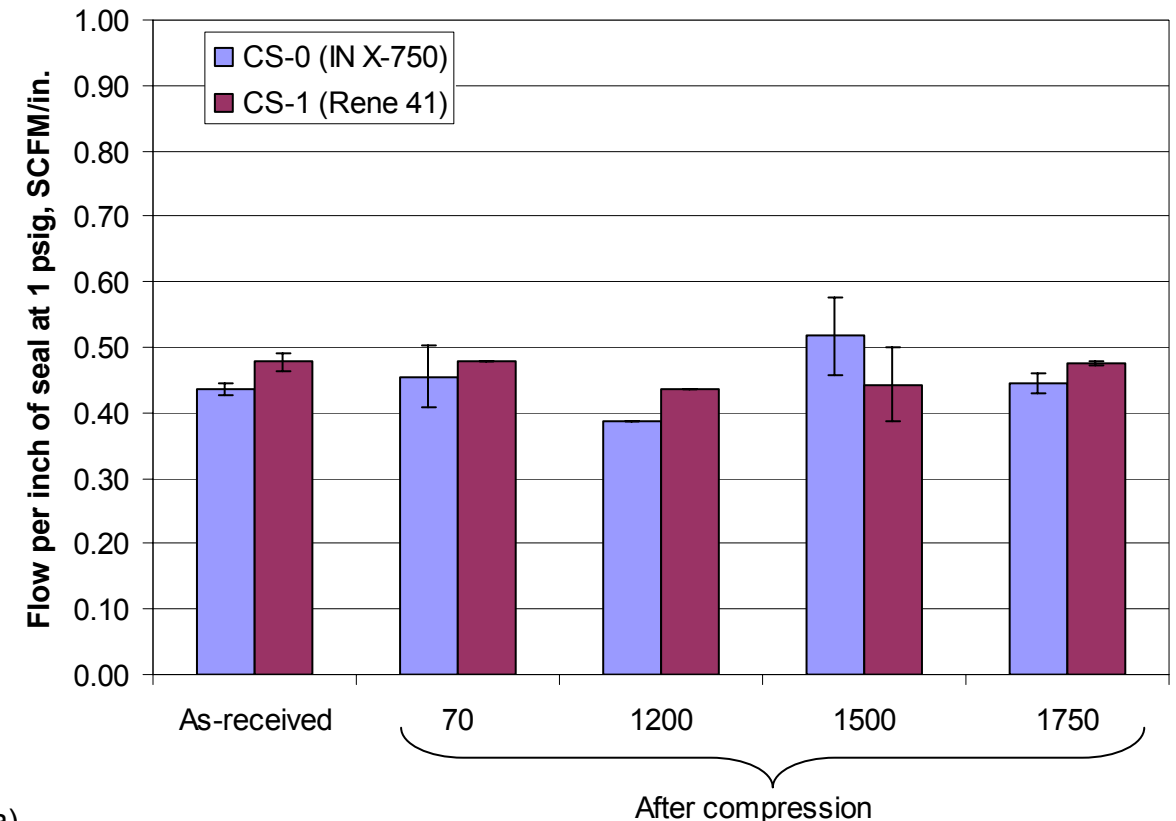

(a)

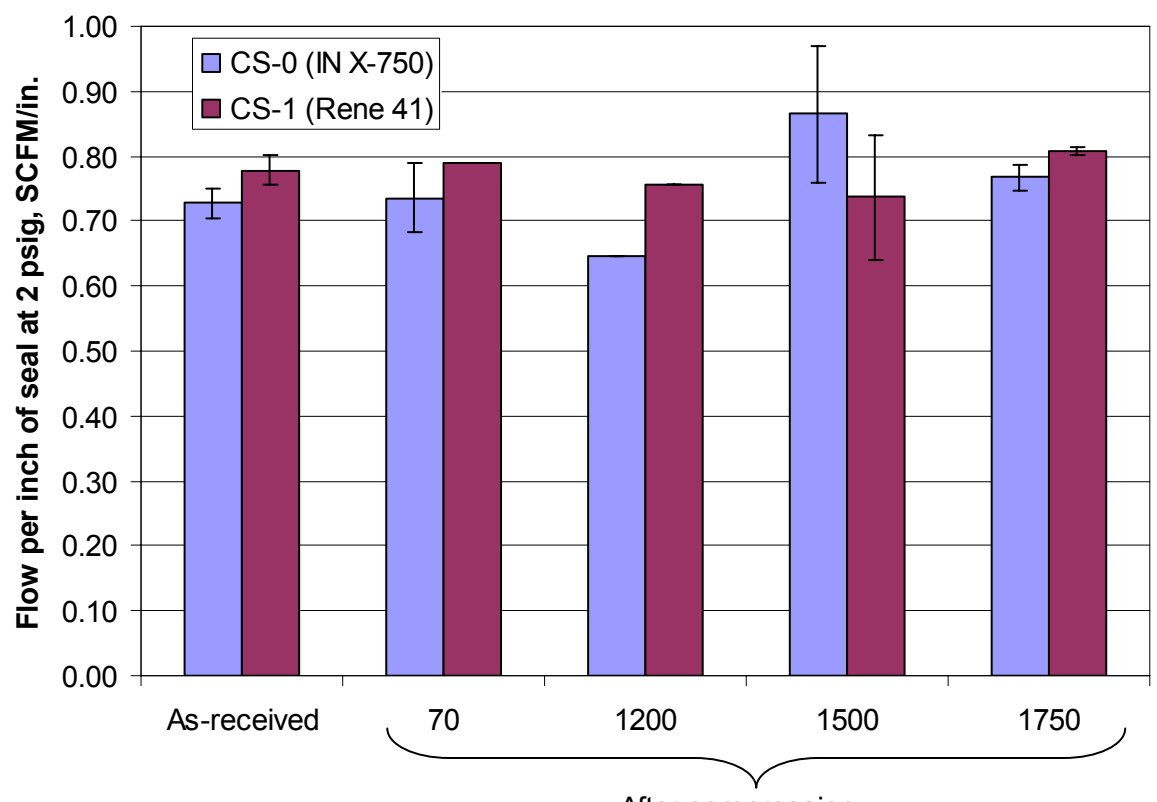

(b)

After compression

Figure 19.-Graph of seal leakage as a function of compression test temperature at a pressure drop of (a) 1 psig and (b) 2 psig. Note: All flow testing was conducted at room temperature. Error bars represent range of values. 


\section{Conclusions}

Thermal barrier seals capable of higher temperatures are required to meet the requirements for future hypersonic vehicles and reentry space craft. A test program was conducted at NASA GRC to examine the benefits of substituting Rene 41 for Inconel X-750 as the knitted spring tube material in the baseline Shuttle-heritage design. The testing was completed to (1) evaluate whether resiliency improvements measured in the spring tube component translated into enhanced performance for the full construction seal and (2) explore other factors contributing to resiliency. Based upon this testing, the following conclusions were noted:

1. Seals with the Rene 41 spring tube exhibited a modest improvement in resiliency ( $\sim 20$ percent) when compared to seals containing an Inconel X-750 spring tube. This enhancement was not quite as pronounced as previously observed during testing of the spring tubes by themselves, suggesting other components in the seal may affect resiliency.

2. Seals incorporating the Rene 41 spring tube exhibited less reduction in resiliency at $1500{ }^{\circ} \mathrm{F}$ when compared to the Inconel X-750 spring tube seals. Between 1200 and $1500^{\circ} \mathrm{F}$, the seals containing the Inconel spring tubes lost 50 percent of their resiliency while seals with the Rene 41 spring tubes lost only 30 percent.

3. Saffil insulation (in the core of the seal) appeared to enhance seal resiliency. At $1750{ }^{\circ} \mathrm{F}$, the addition of $7 \mathrm{pcf}$ Saffil inside an Inconel X-750 spring tube improved resiliency by a factor of almost 10X. When constrained inside a spring tube, the Saffil possesses some intrinsic level of resiliency. The effects from the individual components did not appear to be truly additive, which may help explain why the effect of Saffil in the Rene 41 samples was not as significant.

4. For the range tested, seal resiliency was generally independent of loading configuration (e.g., flat plate vs. groove) and amount of seal lateral compression. As expected, seal load and stiffness increased with additional lateral compression of the seal.

5. Seals made with the Rene 41 spring tube exhibited slightly higher loads than those with the Inconel spring tube (at 7 pcf Saffil packing densities). However, the unit loads were under 5 psi with 20 percent compression at room temperature and therefore would not cause any damage to typical control surfaces.

6. Leakage results demonstrated no significant performance benefit with the seals containing the Rene 41 spring tube. However, in an actual application, these seals would be expected to track gap openings over a wider range when compared to the CS-0 seals. The CS-0 seal design would lose contact with the opposing surface more readily due to its lower resiliency and therefore would have higher leakage when compared to the Rene 41 spring tube seals.

\section{References}

1. Handrick, K.E. and Curry, D.M., "Dynamic and Static High Temperature Resistant Ceramic Seals for X-38 Reentry Vehicle," 53rd International Astronautical Congress, The World Space Congress-2002, Houston, TX, October 2002.

2. Tressen, J.F., "Thermal Barriers for the Space Shuttle," 23rd National Symposium and Exhibition, Society for the Advancement of Material and Process Engineering, Anaheim, CA, May 1978.

3. Dunlap, P.H., Steinetz, B.M., Curry, D.M., DeMange, J.J., Rivers, H.K., and Hsu, S.Y., "Investigations of Control Surface Seals for Re-Entry Vehicles,” NASA/TM-2002-211708, July 2002.

4. Dunlap, P.H., Steinetz, B.M. and Curry, D.M., "Rudder/Fin Seal Investigations for the X-38 Re-Entry Vehicle," NASA/TM-2000-210338/REV1, AIAA-2000-3508, November 2000.

5. DeMange, J.J., Dunlap, P.H., and Steinetz, B.M., "Advanced Control Surface Seal Development for Future Space Vehicles,” NASA/TM-2004-212898, January 2004.

6. Taylor, S.C., DeMange, J.J., Dunlap, P.H., and Steinetz, B.M., "Evaluation of High Temperature Knitted Spring Tubes for Structural Seal Applications," NASA/TM-2004-213183, AIAA-2004-3890, September 2004.

7. Taylor, S.C., DeMange, J.J., Dunlap, P.H., and Steinetz, B.M., "Further Investigations of High Temperature Knitted Spring Tubes for Advanced Control Surface Seal Applications," AIAA-2005-4154, July 2005.

8. Dunlap, P.H., Steinetz, B.M., DeMange, J.J., and Taylor, S.C., "Toward an Improved Hypersonic Engine Seal," NASA/TM-2003-212531, AIAA-2003-4834. 
Public reporting burden for this collection of information is estimated to average 1 hour per response, including the time for reviewing instructions, searching existing data sources, gathering and maintaining the data needed, and completing and reviewing the collection of information. Send comments regarding this burden estimate or any other aspect of this collection of information, including suggestions for reducing this burden, to Washington Headquarters Services, Directorate for Information Operations and Reports, 1215 Jefferson Davis Highway, Suite 1204, Arlington, VA 22202-4302, and to the Office of Management and Budget, Paperwork Reduction Project (0704-0188), Washington, DC 20503.

\begin{tabular}{|l|l|l|}
\hline 1. AGENCY USE ONLY (Leave blank) & $\begin{array}{c}\text { 2. REPORT DATE } \\
\text { October } 2006\end{array}$ & $\begin{array}{r}\text { 3. REPORT TYPE AND DATES COVERED } \\
\text { Technical Memorandum }\end{array}$ \\
\hline
\end{tabular}

4. TITLE AND SUBTITLE 5. FUNDING NUMBERS

Improved Seals for High Temperature Airframe Applications

6. AUTHOR(S)

WBS 394529.02.03.0529.01

Jeffrey J. DeMange, Patrick H. Dunlap, and Bruce M. Steinetz

7. PERFORMING ORGANIZATION NAME(S) AND ADDRESS(ES)

National Aeronautics and Space Administration

John H. Glenn Research Center at Lewis Field

Cleveland, Ohio 44135-3191

8. PERFORMING ORGANIZATION REPORT NUMBER

E-15728

9. SPONSORING/MONITORING AGENCY NAME(S) AND ADDRESS(ES)

National Aeronautics and Space Administration

Washington, DC 20546-0001

10. SPONSORING/MONITORING AGENCY REPORT NUMBER

NASA TM-2006-214465

AIAA-2006-4935

11. SUPPLEMENTARY NOTES

Prepared for the 42nd Joint Propulsion Conference and Exhibit cosponsored by AIAA, ASME, SAE, and ASEE, Sacramento, California, July 9-12, 2006. Jeffrey J. DeMange, University of Toledo, 2801 W. Bancroft Street, Toledo, Ohio 43606-3390; and Patrick H. Dunlap and Bruce M. Steinetz, NASA Glenn Research Center. Responsible person, Jeffrey J. DeMange, organization code RXM, 216-433-3568.

12a. DISTRIBUTION/AVAILABILITY STATEMENT

12b. DISTRIBUTION CODE

Unclassified - Unlimited

Subject Category: 37

Available electronically at http://gltrs.grc.nasa.gov

This publication is available from the NASA Center for AeroSpace Information, 301-621-0390.

13. ABSTRACT (Maximum 200 words)

Current thermal barrier seals, such as those used on the Space Shuttle, are insufficient to fully meet the demands of future hypersonic vehicles and reentry spacecraft. Previous investigations have demonstrated limited usage temperatures, as evidenced by a decreased ability to maintain sealing effectiveness at high temperatures (i.e., inadequate resiliency). In order to improve resiliency at elevated temperatures, Rene 41 (Allvac) was substituted for Inconel X-750 (Special Metals Corp.) as the spring tube material in the existing seal design. A seal construction incorporating the Rene 41 spring tube was fabricated and tested against the baseline Inconel X-750 spring tube seal. Although resiliency improvements were not as dramatic as in previous tests with the spring tubes alone, seals incorporating the Rene 41 spring tube exhibited an average 20 percent resiliency enhancement up to $1750{ }^{\circ} \mathrm{F}$ when compared to seals containing the Inconel spring tube. In addition, the seals with the Rene 41 spring tubes showed less reduction in resiliency as temperatures increased above $1200^{\circ} \mathrm{F}$. Results also indicated the Saffil (Saffil Ltd.) insulation in the core of the seal contributed more to resiliency than previously thought. Leakage data did not demonstrate an improvement with the seal containing the Rene 41 spring tube. However, based upon resiliency results, one could reasonably expect the Rene 41 version of the seal to track gap openings over a wider range. Therefore it would exhibit lower leakage than the Inconel X-750 version as the seal gap opens during a typical mission.

\section{SUBJECT TERMS}

Seals; Flow; Test; High temperature

15. NUMBER OF PAGES

25

16. PRICE CODE

20. LIMITATION OF ABSTRACT

\begin{tabular}{c|c|c}
$\begin{array}{l}\text { 17. SECURITY CLASSIFICATION } \\
\text { OF REPORT } \\
\text { Unclassified }\end{array}$ & $\begin{array}{c}\text { 18. SECURITY CLASSIFICATION } \\
\text { OF THIS PAGE } \\
\text { Unclassified }\end{array}$ & $\begin{array}{c}\text { 19. SECURITY CLASSIFICATION } \\
\text { OF ABSTRACT } \\
\text { Unclassified }\end{array}$
\end{tabular}

NSN 7540-01-280-5500
Standard Form 298 (Rev. 2-89)

Prescribed by ANSI Std. Z39-18 298-102 

